NBER WORKING PAPER SERIES

\title{
WHAT LIES BENEATH THE EURO'S EFFECT ON FINANCIAL INTEGRATION: CURRENCY RISK, LEGAL HARMONIZATION, OR TRADE?
}

\author{
Sebnem Kalemli-Ozcan \\ Elias Papaioannou \\ José-Luis Peydró
}

Working Paper 15034

http://www.nber.org/papers/w15034

\author{
NATIONAL BUREAU OF ECONOMIC RESEARCH \\ 1050 Massachusetts Avenue \\ Cambridge, MA 02138 \\ June 2009
}

Essential parts of this paper were prepared while Sebnem Kalemli-Ozcan was visiting the European Central Bank as 2008 Duisenberg Fellow. She thanks the economists at the Bank for providing a stimulating research environment. We thank Dimitrios Rakitzis for excellent research assistance. Fabio Fiorello from the European Commission and Ana Monteiro from the Legal Department of the ECB helped us gathering and understanding the data related to the implementation of European financial laws. We also thank Simone Manganelli, Philipp Hartmann, Phil Lane, Marco Pagano, Mark Spiegel, Axel Weber, Charles Engel, conference participants at the 5th ECB Central Banking Conference on the Euro at Ten, and two anonymous referees for helpful comments and suggestions. The views expressed in this paper are those of the authors and do not reflect the views of the European Central Bank, the Eurosystem, or the National Bureau of Economic Research.

NBER working papers are circulated for discussion and comment purposes. They have not been peerreviewed or been subject to the review by the NBER Board of Directors that accompanies official NBER publications.

(C) 2009 by Sebnem Kalemli-Ozcan, Elias Papaioannou, and José-Luis Peydró. All rights reserved. Short sections of text, not to exceed two paragraphs, may be quoted without explicit permission provided that full credit, including () notice, is given to the source. 
What Lies Beneath the Euro's Effect on Financial Integration: Currency Risk, Legal Harmonization, or Trade?

Sebnem Kalemli-Ozcan, Elias Papaioannou, and José-Luis Peydró

NBER Working Paper No. 15034

June 2009, Revised March 2010

JEL No. F10,F15,F30

\begin{abstract}
$\underline{\text { ABSTRACT }}$
Although recent research shows that the euro has spurred cross-border financial integration, the exact mechanisms remain unknown. We investigate the underlying channels of the euro's effect on financial integration using data on bilateral banking linkages among twenty industrial countries in the past thirty years. We also construct a dataset that records the timing of legislative-regulatory harmonization policies in financial services across the European Union. We find that the euro's impact on financial integration is primarily driven by eliminating the currency risk. Legislative-regulatory convergence has also contributed to the spur of cross-border financial transactions. Trade in goods, while highly correlated with bilateral financial activities, does not play a key role in explaining the euro's positive effect on financial integration.
\end{abstract}

Sebnem Kalemli-Ozcan

University of Houston

Department of Economics

Houston, TX 77204

and NBER

sebnem.kalemli-ozcan@mail.uh.edu

Elias Papaioannou

Dartmouth College

Department of Economics

Hanover, NH 03755

elias.papaioannou@Dartmouth.EDU
José-Luis Peydró

European Central Bank

29 Kaiserstrasse

Frankfurt am Main,

D60311, Germany

jose-luis.peydro-alcalde@ecb.int 


\section{Introduction}

The introduction of the single European currency has been one of the most important developments in the international markets over the past century. The sixteen European countries that have so far abandoned their national monies and adopted the euro did so expecting that monetary union and the accompanying integration policies would shield their economies from adverse shocks, smooth consumption, and promote non-inflationary growth. On its tenth anniversary, the debate on the costs and benefits of the euro is as intense as ever.

Given the difficulty of measuring the growth benefits of the euro with limited time-series data, the literature has focused on quantifying the effects of the euro on goods trade (see Rose (2009), and Baldwin (2006) for surveys). Examining the effect of the single currency not only on trade, but also on financial integration is fundamental as the free movement of capital across borders is a key prerequisite for the functioning of a currency area (Mundell (1961)). Thus, following the construction of new datasets on cross-border investment for a large number of countries (CPIS data from the IMF), recent studies examine the euro's impact on international capital flows (see Lane (2006b, 2009) and Papaioannou and Portes (2008, 2010) for reviews). ${ }^{1}$ These studies augment an otherwise standard gravity equation of financial holdings/flows with an indicator variable that takes on the value one when the two countries are members of the euro area (and zero otherwise). This approach is certainly the natural first step in analyzing whether financial integration is higher among the euro area countries compared to other economies. Yet, this approach does not identify the sources of the euro's effect on financial integration. As Baldwin (2006) forcefully emphasizes in the similar context of the euro's impact on goods trade, it is vital that we investigate the underlying roots of this effect. For example, is the documented positive effect of the euro on financial integration driven by elimination of the currency risk among member countries? Or is it an outcome of various financial sector legislative-regulatory reforms that European countries undertook simultaneously with the euro's introduction? What if the positive effect of the euro on financial integration is simply due to increased goods trade?

In this paper, we address these questions, which were overlooked by the aforementioned studies

\footnotetext{
${ }^{1}$ Lane (2006a) and Coeurdacier and Martin (2009) estimate that the monetary union increased cross-border bond holdings among the euro area countries by $230 \%$ and $150 \%$ respectively. Similarly Lane and Milesi-Ferretti (2008), Coeurdacier and Martin (2009), and De Santis and Gerard (2006), among others, document that the euro has increased international equity investment among member states by as much as $150 \%$. In the same vein, Spiegel (2009a,b) finds that cross-border bank lending increased three-fold in Portugal and Greece after the euro's introduction. Blank and Buch (2007) find a positive and significant increase in intra-euro area financial linkages following the introduction of the euro.
} 
that investigate the effect of the euro on financial integration. Our main contribution is to identify the sources of the euro's impact on financial integration. ${ }^{2}$ We do so exploiting a unique (confidential) dataset from the Bank of International Settlements (BIS) that reports bilateral cross-border bank assets and liabilities for twenty advanced economies over the past thirty years. Although our focus is primarily in understanding the underlying mechanisms on euro's impact on financial integration, the rich panel structure allows us to perform a comprehensive before-after analysis of the impact of the single currency on cross-border integration accounting for time-invariant country-pair characteristics and global trends. This is important since due to data limitations most previous studies employed cross-sectional approaches. ${ }^{3}$ A natural concern with the cross-sectional estimates in the literature is that they might reflect hard-to-account-for and unobserved country-pair factors that are both correlated with the euro and financial integration. Accounting for such factors is essential, as recent studies show that information asymmetries, distrust and cultural dissimilarities are significant determinants of cross-border investment (e.g. Portes and Rey (2005), Portes et al. (2001), Aviat and Coeurdacier (2007), Guiso et al. (2009), Ekinci et al. (2008); Buch (2003); Gianneti and Yafeh (2008); Mian (2006); Buch, Driscoll, and Ostergaard (2009)).

Thus before we analyze the sources of euro's impact, we start our analysis quantifying the total effect of the single currency on cross-border financial integration. We estimate differencein-difference specifications that compare the "within" country-pair impact of the single currency among the twelve initial euro area member countries (the treatment group) with the general evolution of banking activities across the control group of economies (that consists of other EU and non-EU industrial countries). Our results suggest that following the adoption of the euro bilateral bank holdings and transactions increased by roughly $40 \%$ among the euro area countries. We obtain similar, though somewhat smaller estimates in the range of $25 \%-30 \%$, when we compare the increase in banking integration in the twelve countries that first adopted the euro with the three EU15 nations that have not joined the currency union. Both estimates, although highly significant, are much lower than the ones found in previous studies examining the impact of the single currency

\footnotetext{
${ }^{2}$ In recent work Hale and Spiegel (2009) also investigate the sources of the euro effect using disaggregated firm-level data on bond issuance before and after the euro. They find that after the introduction of the single currency an increased number of mostly non-financial firms issued euro denominated securities.

${ }^{3}$ A notable exception is the study by Blank and Buch (2007), who also also report "within" estimates controlling for country-pair fixed-effects. However their study does not aim to identify the underlying channels of the euro's positive impact on cross-border investment, which is the main question we pursue in this paper.

${ }^{4}$ The parallel literature that assesses the impact of currency unions on trade shows that accounting for countrypair unobservables is fundamental. For example while cross-sectional ("between") studies document that the euro's impact on trade was as large as $200 \%$, the average fixed-effect ("within") estimates falls to $8 \%$ - 12\%, see Rose (2009) and Baldwin (2006).
} 
on various types of capital flows/holdings. This illustrates that failing to account for country-pair fixed-effects and global trends can lead to inflated estimates, due to omitted-variable bias.

After quantifying the total effect of the euro we turn to the main focus of our analysis and investigate the roots of this impact. First, we explore the impact of reducing currency risk and eliminating exchange rate fluctuations among the euro area countries. Among policy circles this was always considered to be the main channel of the euro's impact on financial integration and trade. To isolate the effect of the nature of the currency regime from other policies and developments, we use the recent update of the Reinhart and Rogoff (2004) exchange rate regime classification (from Ilzetzki et al. (2008)) and construct time-varying measures of the flexibility of bilateral exchange rates. This allows us to control for the fall in the exchange rate volatility among the EU currencies in the 1990s before the euro's adoption, when the EU countries joined the exchange rate mechanism (ERMII). Our panel specifications show that international banking activities increase significantly among pairs of countries that adopt hard pegs. Most importantly for our focus, once we control for the nature of the exchange rate regime, the indicator variable that switches to one after 1999 for the euro area countries drops significantly compared to the unconditional specifications; in addition, in most permutations it becomes statistically indistinguishable from zero. This illustrates that the euro's positive effect is mainly driven by elimination of the currency risk. This result is also interesting in the light of the so-called "fear of floating" literature, which argues that due to commitment issues, developing countries are unwilling to let their currencies float (e.g. Calvo and Reinhart (2002); Gelos and Wei (2005)). Our results contribute to this body of work by showing a similar pattern among industrial economies.

Second, we examine the impact of legislative harmonization policies in financial services. Acknowledging that legal, regulatory, and supervisory differences in financial markets are significant impediments to the full integration of capital markets, the EU countries implemented various reforms in banking, insurance, and equity markets over the past decade. Most of these measures were under the umbrella of the Financial Services Action Plan (FSAP), an ambitious initiative launched by the EU Commission and the EU Council in the late 1990s aiming to harmonize the functioning of financial intermediaries. The most important policies of the FSAP were detailed into a set of EU-level laws, the Directives and the Regulations. Among others, the FSAP included new legislation on cross-border M\&A activity of financial institutions, money laundering, transparency in capital markets, investor protection, and supervision (see Table 1 and Supplementary Appendix Table A).

To assess the impact of financial reforms on banking integration, we use information from the 
EU Commission and each of the EU-15 countries and build a new dataset on the implementation of the 27 Directives of the FSAP across member states (see Table 2). In contrast to Regulations that become immediately enforceable across the EU, the Directives are legislative acts that require from member states to achieve some well-specified results, but without clearly dictating the means. Most importantly the EU countries have discretion in the timing of the transposition of the Directives into the domestic legal order. Governments usually delay the transposition of the Directives to national law for various reasons such as technical difficulties in transposing the directives into national law and protecting domestic interests. Hence, the transposition of the Directives takes in practice several years and differs considerably across the EU. As a result, we have significant variation in the adoption time of the 27 legislative acts incorporated in the FSAP.

After constructing this new dataset, we estimate the effects of legislative convergence in the regulation of banking, insurance, company law, and capital markets supervision on financial integration. Our estimates indicate that cross-border banking activities increased significantly among European countries that quickly adopted the financial services Directives of the FSAP. This result contributes to the law and finance literature (La Porta et al. (1997), (1998)), which emphasizes the importance of contracting institutions in shaping financial patterns. To our knowledge, this finding is the first result linking bilateral legislative harmonization to cross-border financial integration. However, although financial services legislative harmonization is a significant driver of banking integration, it cannot explain the total effect of the euro on its own. One explanation might be that the FSAP Directives have not been fully enforced across Europe (see Enriques and Gatti (2007)).

Finally, we investigate whether the spur in cross-border banking integration is driven by an increased volume of transactions in international trade. As goods and asset trade move in tandem (e.g. Obstfeld and Rogoff (2000); Rose and Spiegel (2004); Rose (2005); Aviat and Coeurdacier (2007)) and currency unions raise bilateral trade (e.g. Rose (2000, 2009)), the positive impact of the single currency on financial integration may partly at least be coming from goods trade. Although there is a strong "within" correlation between banking activities and international trade, trade can not explain any part of the effect of the euro on financial integration.

Besides our contribution to the literature on the impact of the single European currency on financial integration and how this impact works, our work relates to the broader literature that examines the determinants of international capital flows. Empirical studies by Wei (2000), Alfaro et al. (2008), Papaioannou (2009) and others show that institutions - broadly defined - are important determinants of all types of international capital flows. Our findings that legal and regulatory harmonization in financial services is strongly associated to international movements illustrates 
that differences in institutions (broadly defined) and the transparency in governance of financial intermediaries are important factors explaining capital flows and the lack of international diversification. Our results further show that, besides institutional frictions, a crucial factor explaining the lack of international diversification is currency risk (see also Gelos and Wei (2005)).

The paper is structured as follows. In the next section we discuss the empirical specification and explain in detail our data. Section 3 gives our estimates on the total effect of the euro, and presents our analysis on the impact of the three aforementioned channels for the impact of the euro on financial integration. Section 4 concludes.

\section{Empirical Specification and Data}

\subsection{Specification}

Our baseline specification takes the following form:

$$
B I_{i, j, t}=\alpha_{i, j}+\alpha_{t}+\psi_{1} E U 1_{i, j, t}+\psi_{2} E U 2_{i, j, t}+\psi_{3} E Z 1_{i, j, t}+\psi_{4} E Z 2_{i, j, t}+X_{i, j, t}^{\prime} \gamma+v_{i, j, t}
$$

The dependent variable $(B I)$ is the average of the log of real bilateral assets and liabilities holdings (or gross flows) of countries $i$ and $j$ in year $t$, standardized by the sum of the two countries' population. We construct $B I$ using data on cross-border banking activities from the confidential version of BIS's International Locational Banking Statistics Database that reports bilateral positions. We extract from this dataset bilateral stocks and flows covering twenty industrialized countries over the period 1977 - 2007. ${ }^{5}$ Our data covers all the twelve initial euro area countries (Austria, Belgium, Germany, Greece, Luxemburg, France, Finland, Netherlands, Spain, Portugal, Ireland, and Italy), plus the three EU15 non-euro area countries (Denmark, Sweden and the United Kingdom), and Australia, Canada, Japan, Switzerland, and the United States. ${ }^{6}$

Our focus is on the coefficient of the $E Z 2_{i, j, t}$ variable that takes on the value one if both countries are members of the eurozone in year $t$ and zero otherwise. To isolate the effect of the single currency

\footnotetext{
${ }^{5}$ The Locational Banking Statistics nowadays covers data from roughly forty countries; yet half of these countries started reporting only recently (mostly after 2000) or are "off-shore" centers. Therefore, we only analyze the twenty industrialized countries that appear in the BIS dataset since 1970s.

${ }^{6}$ Thus the maximum number of observations are $5,700(20 * 19 * 30 / 2)$. Usually bilateral asset and goods trade data contain many zeros that make the logarithmic transformation questionable. Our focus on industrial countries makes our analysis immune to this problem, because we miss just a few observations and only in the beginning of the sample. Our baseline models are estimated in a sample of 5,566 observations. Most gaps involve Greece and Portugal. We thus re-estimated all models dropping these two countries. The results are similar.
} 
from an EU-wide effect, we include in the specification a dummy variable that equals one if the two countries are members of the EU in year $t$ and zero otherwise $\left(E U 2_{i, j, t}\right)$. In all specifications we also control for the unilateral effects of the EU and the euro on banking integration, adding indicator variables that take on the value one when only one of the two countries is a member of the $\mathrm{EU}$ or the euro zone in a given year $\left(E U 1_{i, j, t}\right.$ and $E Z 1_{i, j, t}$ respectively).

The three dimensional panel structure allows us to control for year fixed-effects $\left(\alpha_{t}\right)$ and (more importantly) country-pair fixed-effects $\left(\alpha_{i, j}\right)$. Year fixed-effects account for global trends on banking integration (see Lane and Milesi-Ferretti (2008)), that might be reflected by the euro variable if not controlled. Country-pair fixed-effects control for all time-invariant bilateral characteristics, such as trust, culture, information asymmetries that affect financial patterns. Our empirical model constitutes a difference-in-difference specification, where the euro area member countries are the "treatment" group, while the three EU and the five non-EU countries serve as the "control" group(s). Since we include both time and country-pair fixed-effects the coefficients on the indicator variables measure the effect of the EU and the euro membership on banking integration of the participating countries compared to evolution of international banking integration in the other industrial economies.

Vector $X_{i, j, t}^{\prime}$ includes other independent and control variables, such as trade, the flexibility of the exchange rate regime and legal-regulatory harmonization, which are explained in detail below.

\subsection{Data}

\section{Dependent variable}

The BIS Locational Banking Statistics database covers all of banks' on-balance sheet exposure, as well as some "off-balance sheet" items. The dataset reports asset and liability holdings of banks located in the main industrial countries ("the reporting area") against more than 100 economies (the "vis-a-vis area") since the end of 1977. The data includes mainly cross-border bank-to-bank lending activities, such as foreign loans, deposits and long-term debt placed with non-resident banks, including bank's own related offices abroad and subsidiaries. ${ }^{7}$ The data also covers traderelated credit, and holdings of debt securities issued mainly by other banks, and participations of equity and FDI. Yet, BIS documentations suggests that equity portfolio was, until recently, a small

\footnotetext{
${ }^{7}$ This is the main difference with the similar BIS Consolidated Banking Statistics Database, used for example by Spiegel $(2009 a, b)$. However, Spiegel measures the impact of the euro only for Greece and Portugal.
} 
fraction of international banking activities (see BIS (2003a,b) and Wooldridge (2002)). ${ }^{8}$

Quite importantly domestic monetary authorities report to the BIS the currency exposure of local banking institutions. Using this information the BIS experts can estimate cross-border flows accounting for valuation effects that occur due to exchange rate swings. As the BIS (2003a) documents "flows are estimated by the BIS staff as the exchange rate adjusted changes in holdings." Although from an international diversification standpoint studying stocks is more appropriate, flows account for valuation effects are also important and thus we opt for using both measures. ${ }^{9}$

The data is originally expressed in current U.S. dollars. After deflating the series with the U.S. price index, we construct two measures of banking integration, one based on stocks and one based on gross flows. $B I 1_{i, j, t}$ is the average of the log of real bilateral assets and liabilities holdings of countries $i$ and $j$ in each year, standardized by the sum of the two countries' population. $B I 2_{i, j, t}$ is the average of the log of real bilateral assets and liabilities gross flows, standardized by the sum of the two countries' population in year $t .^{10}$

\section{Exchange rate regime}

To investigate the impact of currency risk we augment our main specification with a bilateral timevarying measure that reflects the flexibility of the exchange rate regime $\left(E R_{i, j, t}\right)$. We do so using the latest update of the Reinhart and Rogoff (2004) exchange rate regime classification (by Ilzetzki, Reinhart and Rogoff (2008)). Using data on official and dual (parallel and black) foreign exchange markets, Reinhart and Rogoff (2004) produce two (de facto) classifications of the exchange rate regime at a monthly frequency from 1946 till the end of 2007. ${ }^{11}$ The "coarse" index distinguishes between four regimes, fixed (score of 1), crawling pegs (score of 2), managed floating (score of 3),

\footnotetext{
${ }^{8}$ Unfortunately the database does not distinguish between FDI, portfolio and fixed-income investments, and standard bank-to-bank loans and credit lines.

${ }^{9}$ de Santis and Gerard (2006) and Buch, Driscoll, and Ostergaard (2009) take a more "structural" approach than we do and compare the actual investment holdings of foreign investors and banks respectively to what an international mean-variance model predicts. While this approach has the obvious benefit of imposing some structure in the empirical analysis it is far from clear than international banks follow simple mean-variance global strategies. For example the corporate finance literature shows that due to monitoring costs and asymmetric information banks tend to lend to proximate borrowers. Moreover since our data includes investment in both debt and equity instruments it is not clear how one could estimate expected international returns.

${ }^{10}$ We also experiment with other measures of banking integration. First, following Rose and Spiegel (2004) we didn't standardize the variables with population (and controlled for the product of log population). Second, following early works on trade we used the log of the average (and alternatively the sum) of bilateral holdings and gross flows (see Baldwin (2006) for a critique of this measure). The results are similar and hence not reported for brevity.

${ }^{11}$ It should be stressed that in our sample of developed economies there are no major black or parallel currency markets. Thus in our group of economies the index is to great extent de jure as it reflects the choice of monetary authorities to peg their currencies.
} 
and free floating (score of 4). ${ }^{12}$ The "fine" grid ranges from 1, indicating a fixed-exchange rate regime (such as the euro), till 13, suggesting a freely floating exchange rate. ${ }^{13}$ For our benchmark estimates we prefer the "fine" classification, as it exhibits larger variation and is less correlated with the binary euro area measure $(E Z 2)$ that we also include in many specifications. We also show results with the "coarse" classification for robustness. For both classifications, we construct a bilateral measure of exchange rate flexibility by taking the sum of the log of the scores for each country in the beginning (as of January) of each year $\left(E R_{i, j, t}^{f, c} \equiv \ln \left(E R_{i, t}^{f, c}\right)+\ln \left(E R_{j, t}^{f, c}\right)\right.$ where superscript $f$ and $c$ indicate the fine and the coarse classification).

\section{Legislative harmonization}

The introduction of the euro was accompanied by legislative reforms in financial services. To isolate the impact of these policies we use information from the European Commission and the EU-15 Member States on the implementation of the Financial Services Action Plan (FSAP) and construct a new dataset that measures the degree of legislative harmonization in financial services across European countries. ${ }^{14}$

The FSAP was a major 5-year program launched by the European Union in the end of 1998 with the aim to establish: (1) a single EU wholesale market for financial services, (2) open and secure retail markets, and (3) state-of-the-art prudential and supervisory regulations. The project included 42 measures that aimed to create a harmonized EU market for banking, securities and insurance. The most important part of the project consisted of (27) EU-level legislative acts (the Directives) and (2) Regulations. The other measures were Communications and Recommendations

\footnotetext{
${ }^{12}$ There is also a fifth category, free falling, that includes hyperinflation currencies. Yet none of the 20 industrialized countries we consider is ever placed in this category.

${ }^{13}$ For example, for most years the U.S. dollar, the Japanese yen, and the Australian dollar get a score around 11 - 13. The Swiss franc ranges from 8 to 12, while the Canadian dollar fluctuates around 8 . The variation in European countries is substantial. In general, European currencies appear in intermediate status for most of the 1980s (in the range of 4 to 8); in the early 1990s the majority of countries move to a fixed-regime range (score of 4 ), and to a fully-fixed regime (score of 1 ) for the ones that join the euro in 1999. The Deutsche mark is classified as a free floating currency (score of 13) till 1998.

${ }^{14}$ Besides legal harmonization in financial services the introduction of the single currency was accompanied by a series of technical/infrastructure reforms. For example with the introduction of TARGET (Trans-European Automated Real-time Gross settlement Express Transfer system) payments between credit institutions within the euro-area take place in real-time and at a harmonized transaction fee. At the same time the number of payment systems was reduced from seventeen to six in 1999. Other important infrastructure innovations included the introduction of the SEPA (Single Euro Payments Area) and the STEP (Short-Term European Paper) platforms that aimed to integrate payments in retail banking and bond markets (see Kalemli-Ozcan, Manganelli, Papaioannou, and Peydro (2010) for a more-in-depth discussion). Since these electronic payment and settlement systems were introduced at the same time in all EU countries, one cannot isolate their impact from that of the elimination of the exchange rate variability.
} 
of the Commission with the member states on technical issues.

Until its official completion at the end of 2003, the EU legislative bodies (the EU Council and the European Parliament with the assistance of the EU Commission) passed most of the initially planned measures. In particular, the EU bodies passed 21 Directives and 2 Regulations. The remaining 6 Directives were initiated with some delay, but their circulation and adaptation for most member-states took place before the end of our sample period (end of 2007). Unlike Regulations that become enforceable immediately after their passage across all EU member states, Directives have to be transposed within a certain period in the legal order of the member states. Usually the transposition time takes a couple of years, as it entails various technical modifications and adaptations. European governments prefer Directives to Regulations, as they can delay the transposition either for technical reasons (some countries need to change internal laws or/and create new institutions to incorporate the directive into national law), or for domestic policy considerations, such as protecting local firms, shielding national industry interests, etc. ${ }^{15}$ Therefore, there is significant heterogeneity on the adaptation timing across countries, which is quite useful for our purposes.

Table 1 gives the title, the date of circulation by the EU Commission, and the deadline for the respective transposition for each of the 27 Directives of the FSAP. Supplementary Appendix Table A provides a brief description of the context of each directive. ${ }^{16}$ While in our analysis we do not distinguish between these legislative acts, it seems that the most important provisions for investors were incorporated in the Prospectus Directive, the Market Abuse Directive, the Takeover Bids Directive and the Transparency Directive (see Enriques and Gatti (2007)). Table 2 reports the date of the transposition for each Directive across all EU15 member states. There is sizable heterogeneity on the timing of the transposition across member states. Take for example the first Directive of the FSAP on Settlements that was circulated by the Commission in late 1998. Only half of the EU-15 countries transposed the Directive in the following year. France, Luxemburg, and Italy took three years to incorporate this Directive into national law. The transposition pace of the Directive on the Supervision of Credit Institutions, Insurance Undertakings and Investment Firms in a Financial Conglomerate was notoriously slow. Although the transposition mandate expired in late 2004 (following an adoption time framework of two years), it was incorporated in time only by

\footnotetext{
${ }^{15}$ Numerous assessments conclude that this system of transposition was too slow, rigid, and failing to distinguish between essential framework principles and implementing rules (see the so-called Lamfalussy report). The Takeovers Directive, for example, had been discussed and negotiated at the EU level for 12 years. Likewise it took more than 30 years for EU governments to agree, vote, transpose and implement the European Company Statute Directive.

${ }^{16}$ All Supplementary Appendix Tables are available at: http://www.dartmouth.edu/ elias/research.html and http://www.uh.edu/ skalemli/papers.html
} 
four countries (namely Denmark, France, Finland and the UK). Most countries took five years to transpose this important financial legislation into national law.

To create the bilateral harmonization variable $\left(H A R M O N_{i, j, t}\right)$ we first define twenty-seven indicator variables that equal one starting at the year of the transposition of each directive into national law in each country, and zero otherwise. Second, we construct a country-level timevarying legal transposition measure ranging from zero to twenty-seven by summing up the values of the indicator variables for each Directive $\left(L E X_{i, t}\right)$. Third, we construct the bilateral harmonization index by taking the sum of the logs of one plus the legislation measure for each country (i.e. $\left.H A R M O N_{i, j, t} \equiv \ln \left(1+L E X_{i, t}\right)+\ln \left(1+L E X_{j, t}\right)\right) .{ }^{17}$ For robustness we also construct the $H A R M O N$ indicator using only the initial twenty-one Directives that were passed by the Commission before the official completion of the FSAP.

\section{Results}

\subsection{Total Effect}

Table 3 reports our results on the total (aggregate) effect of the euro on banking integration. ${ }^{18}$ Columns (1)-(2) of Panel A report unconditional estimates in the maximum sample of twenty countries and thirty years with the stock and the flow based measures of banking integration. The coefficient on $E Z 2$ is positive and statistically significant at the $1 \%$ level in both permutations. This indicates that bilateral banking activities among the euro area countries increased significantly after the adoption of the single currency. In contrast, the EU2 indicator enters with an insignificant estimate. This suggests that it was the adoption of the single currency rather than being a member of the EU that has contributed to the increase in financial integration. The coefficient on EU1 that equals one when one of the two counterparts is a member of the $\mathrm{EU}$ is negative and in most models significant at standard confidence levels. This is due to the fact that cross-border banking activities among the control group of countries (USA, Japan, Switzerland, Australia, and Canada)

\footnotetext{
${ }^{17}$ For robustness we also used the product of the logs of the countries' scores in transposition. We also simply took the sum rather than the sum of the logs of the country measures of legislative harmonization, again finding almost identical results. We prefer the logarithmic transformation because the harmonization variable is skewed. In addition, since the dependent variable is also specified in logs this transformation makes the interpretation of the coefficients easier. We also estimated specifications using a harmonization index that increases when both countries in each country pair have transposed exactly the same Directive (see Supplementary Appendix Table I).

${ }^{18}$ To account for serial correlation and potentially for country-pair specific heteroskedasticity, standard errors are clustered at the country-pair level (Bertrand et al. (2004)).
} 
is quite high, as many of these countries are important financial centers. The coefficient on $E Z 1$ that equals one when one of the two counterparts has adopted the euro is insignificant, suggesting that the unilateral impact was much smaller than the bilateral effect. ${ }^{19}$

While in the specifications reported in columns (1)-(2) we do not condition for other covariates, the inclusion of country-pair fixed-effects accounts for most of the usual control variables of standard gravity equations of financial flows, such as distance, colonial ties, and land areas, all of which have been shown to affect integration. In addition, the country-pair fixed-effects account for other hard-to-measure time-invariant bilateral factors that affect financial linkages, such as trust, cultural similarities, and information asymmetries. Gravity equations typically include the product of bilateral GDPs in the set of explanatory variables. The main idea is that larger-richer economies are able to attract more foreign investment, by providing a larger set of diversification opportunities (e.g. Martin and Rey (2004)) and offering collateral (e.g. Gertler and Rogoff (1990)). In columns (3) and (4) we repeat estimation controlling for the log of the product of real per capita GDP of the two countries in each year (using data from World Bank's World Development Indicators database). GDP is a significant correlate of cross-border financial holdings and transactions, even after conditioning on country-pair unobservables and time trends. Yet the coefficient on the indicator that equals one when both counterparts are members of the euro area $(E Z 2)$ remains significant at the $1 \%$ level.

In columns (5)-(8) we repeat the estimation, dropping observations from the late 1970s and the 1980s. As cross-border banking activities increased drastically since the early 1990s, when the initial stages of the EMU were designed and implemented, it is important to explore the sensitivity of our estimates in this dimension. In addition, focusing in the 1990s and the 2000s allows us to examine the effects of the single currency with the same number of pre and post-1999 observations, something always useful in before-after event studies. The estimate on the indicator that switches to one when both countries join the euro area $(E Z 2)$ is stable and remains highly significant.

The most conservative estimate of the coefficient on EZ2 (in the specifications where we also control for GDP p.c.) implies that - compared to the general increase in banking integration in the group of industrial economies - cross-border banking activities between the euro area countries increased by $40 \%-45 \%$ after the adoption of the single currency $(\exp (0.35)=1.41)$. While this

\footnotetext{
${ }^{19}$ We also specified the $E U 1$ and $E U 2$ indicator variables in an alternative way. Specifically we run models where the $E U 1$ and the EU2 dummies do not include the euro area countries. In these specifications (reported in Supplementary Appendix Table B) the coefficient on the $E Z 2$ indicator is around $0.35-0.40$. The coefficient on $E U 2$ indicator is also positive (around $0.58-0.70$ ), although the estimate is not always statistically significant. In contrast the $E U 1$ and $E Z 1$ variables enter both with insignificant point estimates.
} 
effect is large, it is smaller in magnitude than the estimates of Lane and Milesi-Ferretti (2008), Lane (2006a), de Santis and Gerard (2006) and Coeurdacier and Martin (2009), who, using IMF survey data and cross-sectional approaches, estimate that the euro has increased bilateral equity and bond holdings by around 100\%, if not more. Our more conservative estimates stems from the inclusion of country-pair fixed-effects that accounts for all time-invariant bilateral factors that affect financial linkages. When we do not include country-pair fixed-effects, we also find significantly larger coefficients. We similarly find larger coefficients when we simply control for country (rather than country-pair) fixed-effects or when we perform random effects estimation.

Yet, the interpretation of our within results is somewhat different than the cross-sectional estimates. The coefficient on EZ2 in Table 2 measures the average increase in bilateral banking activities in a pair of countries that has adopted the euro compared to the evolution of international banking activities in the control group of countries. The cross-sectional estimates in contrast measure how much larger are financial linkages of the euro area countries compared to that of other economies in the post-1999 period.

The average bilateral effect of the euro on cross-border banking activities reported in Panel A of Table 3 is also lower than the estimates of Spiegel (2009a,b), who, using BIS consolidated banking statistics for Portugal and Greece over the period 1985 - 2006, finds that the single currency increased banking activities three-fold. Besides the different sample period, the main reason for this difference is the extent of the data. Spiegel $(2009 a, b)$ focuses on two small euro area countries, while we investigate the impact of the single currency in all twelve initial members of the euro area. ${ }^{20}$ We thus explored whether the impact of the single currency was larger for small euro area countries compared to large economies. The estimates (not reported for brevity) are similar for the two group of countries (small and large) and almost identical to the coefficient reported in Panel A of Table $3 .^{21}$ Our results on the bilateral euro effect is also in line (though a bit more conservative) with the estimates of Blank and Buch (2007), who find that the euro increased crossborder bank assets and liabilities by around $80 \%$ and $35 \%$ respectively. While these authors also estimate country-pair fixed-effect models using a similar dataset, their panel just covers five pre and five post 1999 observations. Our much larger time-dimension allows us to better account for

\footnotetext{
${ }^{20}$ While we include in the specification country-pair fixed-effects to account for all time-invariant country-pair factors, Spiegel (2009a,b) includes source-country and recipient-country fixed-effects and directly controls for bilateral gravity factors (such as distance and common language). When we replace the country-pair fixed-effects with country fixed-effects the coefficient on the indicator variable that takes on the value one when both countries are euro area members retains significance and becomes significantly larger, much closer to Spiegel's estimate.

${ }^{21}$ We thank Mark Spiegel for proposing this robustness check.
} 
trends in both the control and the treatment group of countries.

Panel B of Table 3 reports results of otherwise similar to Panel A specifications, estimated only in the EU15 sub-sample. Although in Panel A we control for both unilateral and bilateral effects of EU membership, one may worry that there are different dynamics in the EU and the larger group of industrial countries. To account for this, we re-estimated the specifications in the EU15 sample. The coefficient on the indicator that switches to one for the twelve countries that adopted the single currency after 1999 remains statistically different than zero in all permutations. This reassures that (the more efficient) estimates in the full sample of countries do not reflect an EU-wide effect or different patterns in banking activities in the EU. The coefficient drops somewhat, implying that banking activities among the euro area countries increased by $25 \%(\exp (0.21-0.25)-1=$ $23 \%-29 \%$ ), compared to the evolution of banking integration in the three European countries that have opted out of the currency union.

\subsection{Channels}

We now investigate the role of the exchange rate regime, harmonization policies in financial services, and trade on financial integration. This allows us to understand the underlying reasons for the total effect of the euro documented in Table 3. We start examining the effect of each channel. We then simultaneously control for all of these factors. Finally we explore the sensitivity of our results.

Exchange rate risk The most immediate effect of the euro was to eliminate currency risk among member countries. Even before 1999 exchange rate fluctuations among the legacy currencies were limited. One of the criteria of the Maastricht Treaty of 1992 that set the rules for monetary union was that member countries had to join the exchange-rate mechanism (ERM II) for two consecutive years without devaluating its currency during the period. Yet, although exchange rate variability was lower for European countries participating in the ERM in the nineties than in previous years, foreign investors still had to bear a risk of an abrupt misalignment or a currency attack (as for example in the UK in September of 1992, in France in early 1993, or in Spain in 1992 and 1993).

To investigate the effect of exchange rate variability risk, in columns (1)-(2) of Table 4 we augment the baseline specification with the bilateral exchange rate flexibility measure, $E R_{i, j, t}^{f}$, based on "fine" classification of Reinhart and Rogoff (2004). ${ }^{22}$ The coefficient on the variable that reflects

\footnotetext{
${ }^{22}$ Since the product of $\log$ GDP p.c. enters always with a highly significant coefficient, we always include it in the specifications. The results are similar if we drop this control variable from the estimation.
} 
the bilateral flexibility of the exchange rate regime is negative and significant at the $1 \%$ confidence level. ${ }^{23}$ This suggests that banking activities have increased significantly among pairs of countries that have adopted more rigid currency regimes. This finding fits with the evidence from the "fear of floating" literature (e.g. Calvo and Reinhart (2002); Klein and Shambaugh (2008); Gelos and Wei (2005)). This research argues that in order to attract foreign capital, emerging economies are unwilling to let their currencies float; and even when monetary authorities in developing countries argue that they do not manage the currency in practice they do so (Reinhart and Rogoff (2004)). While this body of work focuses on developing economies, our panel evidence in Table 4 shows a similar pattern across developed countries.

In addition to its direct effect on integration, controlling for exchange rate flexibility also makes the coefficient on the indicator variable that equals one when the two countries are members of the euro area $\left(E Z 2_{i, j, t}\right)$ insignificant. While in some perturbations (reported below in Table 5) the estimate on the $E Z 2$ retains significance, this is only at $10 \%-20 \%$. In addition the estimate falls considerably even when it is significant. This suggests that the positive effect of the single currency mainly comes from the elimination of currency risk.

Legislative Harmonization The euro was supported by various legislative and regulatory harmonization policies in financial services. Although some reforms occurred before 1999 (mainly with the adoption of the First and the Second Banking Directive), European banking markets remained fragmented till the eve of the monetary union (e.g. Hartmann et al. (2003)). The main objective of the Financial Services Action Plan (FSAP) was to tackle this issue and with its various legislative acts to create a single liquid financial market (e.g. Enriques and Gatti (2007)).

In columns (3)-(4) of Table 4, we augment the baseline specification with our newly constructed harmonization index $\left(H A R M O N_{i, j, t}\right)$ that sums the log number of the transposed Directives of the FSAP across the two countries $(L E X)$ in each year. We remove (for the time) the exchange rate regime index from the set of explanatory variables, since we want to investigate the role of each channel one at a time. The coefficient on $H A R M O N$ is positive and significant at the $1 \%$ level. This implies that legislative and regulatory harmonization policies in financial services had a significant positive effect on cross-border banking integration. As we control for EU and euro area membership (with the four indicator variables), the significantly positive estimates on the

\footnotetext{
${ }^{23}$ We also estimated models using the sum of the exchange rate grid of the two countries. The results are similar. We also used the product of the logs of the two countries' classification score. The bilateral exchange rate regime index enters always with a negative and significant estimate.
} 
bilateral harmonization index suggests that legislative harmonization in financial markets also had a first-order effect on cross-border banking integration that works on top of the general positive effect of the euro area membership.

Once we control for legislative-regulatory policies among the EU-members states, the coefficient on the indicator variable that equals one when both counterparts are members of the Eurozone, EZ2, drops compared to the unconditional estimates (in Table 3). It retains significance though (at the 10\%). This suggests that while financial sector harmonization policies did boost cross-border banking activities, the effect of the euro on integration goes only partially through legislative harmonization in financial services.

The significant correlation between legislative harmonization and financial integration reveal that legal system differences may explain the lack of international diversification. The empirical literature on law and finance shows that country-level differences in investor protection can explain a sizable portion of the size of domestic financial markets (see La Porta et al. (2008) for a review). Our results contribute to this body of work by showing that legal harmonization has also an effect on bilateral financial linkages and can thus explain the lack of cross-border investment (see Shleifer and Wolfenzon (2003) for a theoretical exposition). Most likely the effect of legislative harmonization policies in financial services is larger than our estimates suggest, since our index contains some measurement error. The transposition of the Directives into the domestic legal order differs to some extent across the EU. Some countries for example implement stricter regulatory practices than the ones specified in each Directive, while other countries go for minimum harmonization (see Enriques and Gatti (2007) for a detailed analysis). Moreover some Directives leave considerable room to member states for modifications, exemptions, and partial implementation (as for example the Takeover Bids Directive), while other Directives are quite comprehensive detailing all necessary ingredients of domestic legislation (as for example the Market Abuse Directive and to a lesser extent the Prospectus Directive). Most importantly, actual enforcement of the EU legislation differs considerably across the EU (e.g. Djankov et al. (2003, 2008)) and thus the de-facto impact of the transposition might also be different than the de-jure effect that our estimates reflect.

Trade Are trade in goods and trade in assets complements or substitutes? While it is quite challenging to establish causation, ample studies show a strong correlation between trade and financial integration (see for example Aviat and Coeurdacier (2007)). A volumious literature also shows that 
the euro had a positive effect on goods trade. ${ }^{24}$ Thus, another potential channel explaining the spur in financial integration among the euro area countries compared to other developed economies could stem from increased trade in goods. To account for this channel, in columns (5) and (6) of Table 4, we augment the baseline specification with the average of the log of bilateral exports and imports as a share of the two countries' population $\left(T R A D E_{i, j, t}\right)$, using data from IMF's Direction of Trade Database. ${ }^{25}$

The coefficient on $T R A D E_{i, j, t}$ is positive and significant, suggesting that trade in goods and bank claims go in tandem (e.g. Rose and Spiegel (2004) and Rose (2005)). Compared to the previous literature our results demonstrate that the strong trade-finance nexus is present even when we control for country-pair fixed-effects and global trends. Yet, trade linkages cannot explain the total impact of the euro on integration at all. The coefficient on the $E Z 2$ indicator in columns (5)-(6) is quite similar to the analogous estimates in Table 3. In addition the estimate remains statistically significant at the $1 \%$ level. Thus while trade is a significant correlate of financial integration, it can not account for the large effect of monetary union documented in Table 3.

All channels There is a possibility that each channel is proxying one another. Thus, in Table 5 we augment the specification with all three variables that capture the exchange rate channel, the legislative harmonization policies in financial markets, and trade. We also explore the sensitivity of our results by presenting results with the alternative exchange rate index $\left(E R^{c}\right)$ based on the "coarse" regime classification (in columns (5)-(8)) and the harmonization index (HARMON) using only the initial 21 Directives of the FSAP (in columns (3), (4), (7), and (8)). As we lose $15 \%$ of our sample when we control for trade (due to some gaps on IMF's Direction of Trade Statistics), in Table 6 we report otherwise identical to Table 5 specifications, but without trade in the RHS. ${ }^{26}$

The $E R$ index that sums (the log) of the exchange rate regime index of the two countries enters with a negative coefficient in all permutations of Tables 5 and 6 . The coefficient drops by $20 \%-50 \%$ compared to the estimates in columns (1)-(2) of Table 4, where we didn't control for legislative harmonization policies in financial services and trade. Yet the estimate is statistically

\footnotetext{
${ }^{24}$ While initial (cross-sectional) studies document an (unrealistically) high effect (e.g. Rose (2000)), recent (panel) studies estimate that the single currency increased bilateral trade approximately by $8 \%-14 \%$ (e.g. Flam and Nordstrom (2008)).

${ }^{25}$ We also experiment with other measures of trade, such as the (log and the level) of average bilateral exports and imports as a share of GDP, finding similar results.

${ }^{26}$ Supplementary Appendix Table C reports analogous specifications but with an alternative way to specify the 4 $\mathrm{EU}$ and EMU indicator variables. In these specifications the $E U 1$ and the EU2 dummies do not include the euro area countries.
} 
significant in all but two of the sixteen specifications. Turning now to the effect of legislative harmonization policies in financial markets, the results in Tables 5 and 6 show that the FSAP had a significantly positive impact on spurring cross-border banking activities across Europe. In all specifications the harmonization index enters with a coefficient that is at least two standard errors above zero. The estimate (around $0.07-0.09$ ) is also quite similar to the more parsimonious specifications in columns (3)-(4) of Table 4. As we control for exchange rate fluctuations, GDP differences, and trade, this result is encouraging for European policy makers, who are in the process of further promoting legislative and regulatory harmonization in financial markets. Trade continues to enter with a significantly positive elasticity. As long as the estimate is not driven exclusively by reverse causation, this suggests that besides more immediate effects, the euro could speed financial integration indirectly through goods market integration.

To get an estimate of the relative importance of the three channels we also estimated standardized beta coefficients. The average value of the beta coefficient for the bilateral exchange rate index in Table 5 is -0.06 . This implies that a one standard deviation fall in $E R$ that makes the exchange rate regime more rigid is associated with a 0.06 increase in the dependent variable. The average value of the standardized coefficient for the bilateral harmonization index $(H A R M O N)$ is somewhat larger, 0.075, while trade's beta coefficient is on average 0.14.

In almost all perturbations in Tables 5 and 6 the coefficient on EZ2 turns insignificant. Even in the specifications that the estimate retains significance, this is borderline and the coefficient drops considerably compared to the unconditional estimates in Table 3. Combined with the results in Table 4, the elimination of exchange rate risk seems to be the most important channel. Yet, legislative harmonization policies in financial services have also crucially contributed to the spur of cross-border financial linkages across the EU in the past decade. In contrast goods trade, while a highly significant correlate of banking integration (with the largest "standardized" coefficient), is not behind the large unconditional effect of the single currency documented in Table $3 .^{27}$

Sensitivity Analysis We explored extensively the sensitivity of our results. As already shown in Table 3 we estimated the specifications only in the 1990s and the 2000s to account for potentially different dynamics in the two sub-periods. Moreover, as the results in Tables 5 and 6 show our results are not sensitive to different ways measuring the nature of the exchange rate regime or the

\footnotetext{
${ }^{27}$ This is not to say that other policies and reforms did not have any effect. The EMU project included many policies that is hard-to-precisely pin down and measure. See Kalemli-Ozcan et al. (2010) for a detailed summary of the technical and infrastructure steps that the EU bodies have taken to homogenize the various market segments for financial services.
} 
legislative harmonization policies of the FSAP.

In Table 7 we check whether the results are driven by Luxemburg and Switzerland, the two countries with the largest share of foreign bank and liabilities in our sample. ${ }^{28}$ Columns (1)-(4) report simple specifications (analogous to the models in Table 3) that estimate the total effect of the single currency on banking integration. The coefficient on the indicator variable that takes on the value one when both countries are members of the euro area retains its economic and statistical significance. The most conservative estimate in column (4) implies that following the adoption of the euro cross-border banking activities by approximately 50\%, compared to the general increase in the other industrial economies $(\exp (0.402)=1.49)$. Yet once we control for the nature of the exchange rate regime and legislative harmonization (in (5)-(6)) the estimate on EZ2 turns insignificant as in our previously reported results; and although trade in goods is correlated with banking activities (column (7)-(8)), this cannot account for the effect of single currency on financial integration.

In Table 8 we control for structural features of the domestic banking system in countries $i$ and $j$. This is a necessary robustness check as there is concern that the implementation of the FSAP directives was driven by local conditions in the banking system. ${ }^{29}$ We do so using three timevarying proxies of bank's health and profitability from the latest update of World Bank's Financial Structure Database (Beck, Demirgüç-Kunt, and Levine (2000)). In columns (1)-(2) we control for banks' overhead costs, while in (3)-(4) we control for banks' profitability using the average value of banks' net interest revenue as a share of total assets (the Data Appendix gives detailed variable definitions). Both measures of banking performance enter with insignificant estimates. In (5)-(6) we control for competition in the banking system with a concentration index that equals the share of the assets of three largest banks as a share of assets of all commercial banks. The coefficient is indistinguishable from zero. More importantly, controlling for structural features of the banking system has no effect on our main results. Cross-border banking activities increase significantly when countries adopt more rigid exchange rate arrangements (such as joining the euro). Moreover, international financial linkages are stronger among countries with more similar legal and regulatory rules in financial services.

We have performed many other sensitivity checks: ${ }^{30}$ First, to partly account for reverse causa-

\footnotetext{
${ }^{28}$ The results are similar if we exclude only Luxemburg or only Switzerland or if we also drop the United Kingdom. ${ }^{29}$ We thank an anonymous referee for pointing out this possibility.

${ }^{30}$ All Supplementary Appendix Tables with the additional sensitivity checks are available at: http://www.dartmouth.edu/ ${ }^{\sim}$ elias.
} 
tion we have run regressions using lagged values of all explanatory variables (see Supplementary Appendix Table D). We have also estimated 2SLS specifications using lagged trade as an instrument for contemporaneous trade (see Supplementary Appendix Table E). The results are quite robust and the estimates unaffected. Second, we have also analyzed assets and liabilities separately, as there is always a possibility that the euro might have affected them differently. The regressions (reported on Supplementary Appendix Table F) show similar patterns. Third, we also controlled for a bilateral measure of nominal exchange rate volatility (following Devereux and Lane (2003)). Again all our results are robust to the inclusion of this control, which (as in and Lane (2006a)) appears with an insignificant coefficient (Supplementary Appendix Table G). The insignificant effect of nominal exchange rate volatility suggests that foreign banks were particularly concerned with currency risk rather than with (relatively small) swings in the exchange rate. Fourth, we used an alternative legislative harmonization index in financial services that changes when the two countries have adopted exactly the same Directive. The results (reported in Supplementary Appendix $\mathrm{H})$ are unchanged and if anything stronger. Finally, although the universal banking structure in Europe (see Allen et al. (2004)) implies that all the FSAP directives are relevant for banks, we also specified a banking legislative harmonization measure that only reflects the Directives that are relatively more relevant to banking (i.e. excluding those ones which are relatively more important for security and insurance markets) finding similar results (Supplementary Appendix Table I). ${ }^{31}$

\section{Conclusion}

The introduction of the euro has been one of the most important policy experiments in international economics over the past decades. The initial focus of the literature was to investigate the effect of the euro on trade integration. Following the development of new datasets on cross-border investment, recent studies examine the euro's impact on financial integration, documenting a large effect. Yet, we still do not know the exact mechanism through which the euro affects financial integration. This is the main task we undertook in this paper.

We construct a new dataset of legislative-regulatory harmonization policies in financial intermediation across the European Union in the last decade and then merge it with the confidential version of BIS's Locational Banking Statistics that records bilateral financial linkages among twenty

\footnotetext{
${ }^{31}$ In particular, in Supplementary Appendix Table I we use the directives numbered 2, 5, 8, 14, 19, 26 and 27 of Table 1. This follows the recent Commission study on the evaluation of the FSAP by Malcolm, Tilden and Wilsdon (2009)). We are grateful to Ana Margarida Monteiro, and the other experts of the ECB Financial Law department for clarifying these issues.
} 
industrial countries in the past thirty years. The rich panel structure allows us to reassess the euro's impact on financial integration accounting for all time-invariant country-pair factors, such as trust, culture, and information frictions.

First, our "within" before-after analysis shows that while the total effect of the euro on financial integration is highly significant, it is quantitatively much smaller from what has been reported in the previous studies that relied on cross-sectional approaches and data covering the last decade.

Second, our "channels" analysis shows that the euro's impact is primarily driven by the elimination of currency risk across member countries. We also document that legislative-regulatory harmonization policies in financial markets, albeit far from perfect (Enriques and Gatti (2007), have contributed significantly to the spur of cross-border lending and investment across Europe; these integration reforms therefore explain a sizable portion of the aggregate effect of the euro. In contrast, while goods trade is a significant correlate of cross-border lending, it can not explain the euro's large impact on financial integration.

Our results have some straightforward policy implications. The fact that legislative-regulatory harmonization policies have a direct effect on financial integration on top of all the other channels and country/time factors is quite encouraging for European policy makers, who are currently in the process of promoting further harmonization. Future research should investigate the effect of such legislative reforms on other aspects of integration, such as cross-border M\&A activity, vertical and horizontal FDI, outsourcing, return co-movement, and risk-taking by banks. 


\section{Data Appendix}

Banking Integration 1 [BI1]: Banking integration index based on bilateral cross-border holdings (stocks) of banks. Data on bank's cross-border bilateral stocks of assets and liabilities come from the confidential version of BIS's Locational Banking Statistics. For each country-pair and year there are up to four observations. $i$ ) asset holdings (stocks) of banks located in country $i$ in all sectors of the economy in country $j$; $i i$ ) asset holdings (stocks) of banks located in country $j$ in all sectors of the economy in country $i$; iii) liabilities (stocks) of banks located in country $i$ to country $j$. iv) liabilities (stocks) of banks located in country $j$ to country $i$. The data is originally expressed in current US dollars. First, we deflate the four series with the US deflator. Second, we standardize the series by dividing asset and liabilities with the sum of the two countries population in each year (using data from World Bank's World Development Indicators Database). Third, we take the average of the log value of real bilateral assets and liabilities in each year. Source: Bank of International Settlements, Locational Banking Statistics (2008).

Banking Integration 2 [BI2]: Banking integration index based on bilateral cross-border gross flows of banks. Data on bank's cross-border bilateral gross flows of assets and liabilities come from the BIS Locational Banking Statistics. For each country-pair and year there are up to four observations. $i$ ) asset flows of banks located in country $i$ in all sectors of the economy in country $j$; ii) asset flows of banks located in country $j$ in all sectors of the economy in country $i$; $i i i$ ) liability flows of banks located in country $i$ to country $j$. iv) liability flows of banks located in country $j$ to country $i$. The data is originally expressed in current US dollars. First we deflate the four series with the US deflator. Second we take the absolute value of (net) flows. Third, we standardize the series, by dividing asset and liability flows with the sum of the two countries population in each year (using data from World Bank's World Development Indicators Database). Fourth, we take the average of the log value of real bilateral gross flows in assets and liabilities in each year. Source: Bank of International Settlements, Locational Banking Statistics (2008).

Euro Area Both $[E Z 2]$ : Bilateral index of membership in the euro area. The measure is an indicator variable that takes on the value one if both countries are members of the euro-zone in year $t$ and zero otherwise. Source: European Central Bank.

Euro Area One [EZ1]: Bilateral index of membership in the euro area. The measure is an indicator variable that takes on the value one if only one country is member of the euro-zone in year $t$ and zero otherwise. Source: European Central Bank. 
European Union Both [EU2]: Bilateral index of membership in the EU. The measure is an indicator variable that takes on the value one if both countries are members of the EU in year $t$ and zero otherwise. Source: EU Commission.

European Union One [EU1]: Bilateral index of membership in the EU. The measure is an indicator variable that takes on the value one if only one country is member of the EU in year $t$ and zero otherwise. Source: EU Commission.

Exchange Rate Flexibility $[E R]$ : Bilateral index of the flexibility of the exchange rate, based either on the "fine" or "coarse" regime classification of Reinhart and Rogoff (2004). In the "fine" classification the country-specific index ranges from 1 to 14 where lower values suggest a more rigid regime, whereas in the "coarse" classification the index ranges from 1 to 5 . We construct the bilateral index by taking the sum of the log classification of countries $i$ and $j$ in the beginning (January) of each year $t\left(E R_{i, j, t}=\ln \left(E R_{i, t}\right)+\ln \left(E R_{j, t}\right)\right)$. Source: Ilzetzki, Reinhart, and Rogoff (2008) and Reinhart and Rogoff (2004).

Nominal Exchange Rate Volatility [ERVOL]: Standard deviation of the log first difference of the monthly bilateral exchange rate for each year over the period $1978-2007$. VOLERij $=$ $S T D E V_{t}\left[\Delta \ln \left(e_{i, j, m}\right)\right]$ where $e_{i, j, m}$ is the monthly nominal exchange rate between countries $i$ and $j$. The index follows Devereux and Lane (2003). Source: ECB.

Legislative Harmonization in Financial Services [HARMON]: Index of regulatorylegislative harmonization in financial services based on the transposition of the Directives of the Financial Services Action Plan (FSAP). The FSAP was launched in 1998 and included 27 EUwide legislative acts (the Directives) that require from member countries to transpose in due time to the domestic legal order. Until the official completion of the plan in the end of 2003, the EU legislative bodies (the Commission and the Council) had initiated 21 of these laws. The remaining 6 Directives were initiated before the end of our sample and thus we include them in our analysis. However, Directives do not become immediately enforceable across the EU. EU member states have considerable discretion in the transposition (adoption) of these acts. We construct the bilateral harmonization index in three steps. First, for each country we define 27/21 indicator variables that equal one starting at the year of the transposition of each Directive into national law and zero otherwise. Second, we create a country-time varying legislation measure ranging from 0 to $27 / 21$ by summing the values of the $27 / 21$ indicator variables for each country $\left(L E X_{i, t}\right)$. Third, we take the sum of the log value of the legislation measure for each country in each year (i.e. $\left.H A R M O N_{i, j, t} \equiv \ln \left(1+L E X_{i, t}\right)+\ln \left(1+L E X_{j, t}\right)\right)$. The data is retrieved from the EU Commission's 
league tables (http://ec.europa.eu/internal_market/finances/index_en.htm). The Commission also provides links to the national legislative acts of the EU15 member countries. We were thus able to track down the exact timing of national legislative acts that transposed the Directives. Source: EU Commission League Tables.

Alternative Legislative Harmonization in Financial Services [HARMON-ALT]: Alternative index of regulatory-legislative harmonization in financial services based on the transposition of the Directives of the Financial Services Action Plan (FSAP). The index is constructed in two steps. First, for each country-pair we define 27 indicator variables. Each dummy variable $\left(L E X-A L T_{i, j, t}\right)$ equals one starting at the year of the transposition of each Directive into national law by both countries and zero otherwise. Second, we we create the alternative legislative harmonization measure by summing the values of these 27 indicator variables $\left(L E X-A L T_{i, j, t}\right)$. $H A R M O N-A L T_{i, j, t} \equiv \ln \left(\sum_{k=1}^{K=27} L E X-A L T_{i, j, t}\right)$. The results with this index are reported in Supplementary Appendix Table H. Source: EU Commission League Tables.

Banking Legislative Harmonization in Financial Services [HARMON-BANK]: The index of legislative harmonization policies in banking is based on the Directives of the the Financial Services Action Plan (FSAP). Using the classification of the Directives into banking, insurance, and capital markets (from Malcolm, Tilden, and Wilsdon (2009)) we construct this measure similarly to the HARMON index, but we use information only on the seven Directives that were more relevant for banking activities. These Directives are numbered 2, 5, 8, 14, 19, 26 and 27 in Tables 1 and 2. See also Supplementary Appendix Table A. The results with this index are reported in Supplementary Appendix Table I. Source: EU Commission League Tables.

Trade $[T R A D E]$ : Index of bilateral trade intensity/integration. The measure is the log of bilateral real (deflated with the US price deflator) exports and imports as a share of two country's population. Source: IMF's Direction of Trade Database (2008).

Real Per Capita GDP $[G D P]$ : Index of the economic importance of the two countries. The measure is the log of the product of real per capita GDP of the two countries in each year. Source: World Bank's World Development Indicators Database (2008).

Bank Net Interest Margin [MARGIN]: Accounting value of bank's net interest revenue as a share of its interest-bearing (total earning) assets. Source: Financial Structure Database, Beck, Demirgüç-Kunt and Levine (2000). Original Source: Fitch's BankScope Database.

Bank Overhead Costs [OVERHEAD]: Accounting value of a bank's overhead costs as a share of its total assets. Source: Financial Structure Database, Beck, Demirgüç-Kunt and Levine 
(2000). Original Source: Fitch's BankScope Database.

Bank Concentration Index [CONCENTRATION]: Assets of three largest banks as a share of assets of all commercial banks. Source: Financial Structure Database, Beck, DemirgüçKunt and Levine (2000). Original Source: Fitch's BankScope Database. 


\section{References}

[1] Alfaro, L., Kalemli-Ozcan, S., Volosovych, V., 2008. Why doesn't capital flow from rich to poor countries? An empirical investigation. Review of Economics and Statistics 90(2), 347-368.

[2] Allen, F., Chui, M., Maddaloni, A., 2004. Financial systems in Europe, the USA and Asia. Oxford Review of Economic Policy 20(4), 490-508.

[3] Aviat, A., Coeurdacier, N., 2007. The geography of trade in goods and assets. Journal of International Economics 71(1), 22-51.

[4] Baldwin, R. A., 2006. The euro's trade effects. ECB Working Paper Series No. 594.

[5] Bank of International Settlements, Monetary and Economic Department, 2003a. Guide to international financial statistics. BIS (Basle, Switzerland) Papers No. 14, February.

[6] Bank of International Settlements, Monetary and Economic Department 2003b. Guide to international banking statistics. BIS (Basle, Switzerland) Papers No. 16, April.

[7] Bertrand, M., Duflo, E., Mullainathan, S., 2004. How much should we trust difference in differences estimates? Quarterly Journal of Economics 119(1), 249-275.

[8] Blank, S., Buch, C., 2007. The Euro and cross-border banking: evidence from bilateral data. Comparative Economic Studies 49(2), 389-410.

[9] Buch, C., 2003. Information or regulation: what drives the international activities of commercial banks? Journal of Money, Credit, and Banking 35(6), 851-869.

[10] Buch, C., Driscoll, J., Ostergaard, C., 2009. Cross-border diversification in bank asset portfolios. Unpublished manuscript.

[11] Calvo G., Reinhart, C., 2002. Fear of floating. Quarterly Journal of Economics 117(2), 379-408.

[12] Coeurdacier, N., Martin, P., 2009. The geography of asset trade and the euro: insiders and outsiders. Journal of the Japanese and International Economies 23(2), 90-113.

[13] De Santis, R., Gerard, B., 2006. Financial integration, international portfolio choice and the European monetary union. ECB Working Paper No. 626.

[14] Devereux, M., Lane, P., 2003. Understanding bilateral exchange rate volatility. Journal of International Economics 60(1), 109-132. 
[15] Djankov, S., La Porta, R., Lopez-de-Silanes, F., Shleifer, A., 2003. Courts. Quarterly Journal of Economics 118(2), 453-517.

[16] Djankov, S., La Porta, R., Lopez-de-Silanes, F., Shleifer, A., 2008. The law and economics of self-dealing. Journal of Financial Economics 88(3), 430-465.

[17] Ekinci M., Kalemli-Ozcan, S., Sørensen, B., 2008. Financial integration within EU Countries: the role of institutions, confidence and trust. NBER Working Paper 13440.

[18] Enriques, L., Gatti, M., 2007. Is there a uniform EU securities law after the Financial Services Action Plan? SSRN, Mimeo.

[19] Flam, H., Nordström, H., 2006. Euro effects on the intensive and extensive margins of trade. IIES Seminar Paper No. 750. Revised version available at: http://www-2.iies.su.se/ ${ }^{\sim}$ flamh/.

[20] Forum on Cross-Border Financial Groups, 2009. Cross-border banking in Europe: what regulation and supervision? Unicredit Group Discussion Paper. Available at: http://www.unicreditgroup.eu/.

[21] Gelos, G. R., Wei, S.-J., 2005. Transparency and international investor behavior. Journal of Finance 60(6), 2987-3020.

[22] Gertler, M., Rogoff, K., 1990. North-south lending and endogenous capital market inefficiencies. Journal of Monetary Economics 26(2), 245-266.

[23] Giannetti, M., Yafeh, Y., 2008. Do cultural differences between contracting parties matter? Evidence from syndicated bank loans. ECGI Finance Working Paper No. 224/2008.

[24] Guiso, L., Sapienza, P., Zingales, L., 2009. Cultural biases in economic exchange? Quarterly Journal of Economics 124(3), 1095-1131.

[25] Hale, G., Spiegel, M., 2009. Who drove the boom in euro denominated bond issues? Federal Reserve Bank of San Francisco Working Paper Working Paper 2008-20.

[26] Hartmann, P., Maddaloni, A., Manganelli, S., 2003. The Euro-area financial system: structure, integration and policy initiatives. Oxford Review of Economic Policy 19(1), 280-313.

[27] Ilzetzki E., Reinhart, C. M., Rogoff, K. S., 2008. Exchange rate arrangements entering the 21st century: which anchor will hold? Mimeo. Data available at: http://www.economics.harvard.edu/faculty/rogoff/Recent_Papers_Rogoff. 
[28] Kalemli-Ozcan, S., Manganelli, S., Papaioannou, E., Peydró, J.-L., 2010. Financial integration and risk sharing: the role of monetary union, forthcoming in: Reichlin, L. (Ed.), The Euro at Ten, 5th European Central Banking Conference, ECB.

[29] Klein, M. and Shambaugh, J., 2008. The dynamics of exchange rate regimes: fixes, floats, and flips. Journal of International Economics 75(1), 70-92.

[30] La Porta, R., Lopez-de-Silanes, F., Shleifer, A., Vishny, R., 1997. Legal determinants of external finance. Journal of Finance 52(3), 1131-1150.

[31] La Porta, R., Lopez-de-Silanes, F., Shleifer, A., Vishny, R., 1998. Law and finance. Journal of Political Economy 106(6), 1113-1155.

[32] La Porta, R., Lopez-de-Silanes, F., Shleifer, A., 2008. The economic consequences of legal origins. Journal of Economic Literature 46(2), 285-332.

[33] Lane, P.R., 2006a. Global bond portfolios and EMU. International Journal of Central Banking 2(1), 1-23.

[34] Lane, P.R., 2006b. The real effects of european monetary union. Journal of Economic Perspectives 20(1), 47-66.

[35] Lane, P.R., 2009. EMU and financial integration, forthcoming in: Reichlin, L. (Ed.), The Euro at Ten, 5th European Central Banking Conference, ECB.

[36] Lane, P. and Milesi-Ferretti, G. M., 2008. International investment patterns. Review of Economics and Statistics 90(3), 538-549.

[37] Malcolm, K., M. Tilden, T. Wilsdon., 2009. Evaluation of the economic impacts of the financial services action plan. CRA International report prepared for the European Commission, Internal Market and Services DG.

[38] Martin, P., Rey H., 2004. Financial supermarkets: size matters for asset trade. Journal of International Economics 64(2), 335-361.

[39] Mian, A., 2006. Distance constraints: the limits of foreign lending in poor economies. Journal of Finance 61(6), 1465-1505.

[40] Mundell, R., 1961. A theory of optimum currency areas. American Economic Review 51(4), 509-517. 
[41] Obstfeld, M., Rogoff, K., 2000. The six major puzzles in international economics: is there a common cause? In NBER Macroeconomics Annual 2000, University of Chicago Press, Chicago, ILL.

[42] Papaioannou, E., 2009. What drives international financial flows? Politics, institutions and other determinants. Journal of Development Economics 88(2), 269-281.

[43] Papaioannou, E., Portes, R., 2009. Costs and benefits of running an international currency. European Commission, DG-EC/FIN, Special Report on the European Economy, forthcoming.

[44] Papaioannou, E., Portes, R., 2010. The international role of the euro: a status report, forthcoming in: EMU@10, Buti, M., Deroose, S., Gaspar, V. (Eds), European Commission, DGEC/FIN, European Economy Economic Papers, pp 317.

[45] Portes, R., Rey, H., 2005. The determinants of cross-border equity flows. Journal of International Economics 65(2), 269-296.

[46] Portes, R., Rey, H., Oh, Y., 2001. Information and capital flows: the determinants of transactions in financial assets. European Economic Review (Papers and Proceedings) 45(4-6), $783-796$.

[47] Reinhart, C., Rogoff, K., 2004. The modern history of exchange rate arrangements: a reinterpretation. Quarterly Journal of Economics 119(1), 1-48.

[48] Rose, A., 2000. One market, one money: estimating the effect of common currencies on trade. Economic Policy 30(1), 7-45.

[49] Rose, A., 2005. One reason countries pay their debts: renegotiation and international trade. Journal of Development Economics 77(1), 189-206.

[50] Rose, A., 2009. Is EMU becoming an optimum currency area? The evidence on trade and business cycle synchronization, forthcoming in: Reichlin, L. (Ed.), The Euro at Ten, 5th European Central Banking Conference, ECB.

[51] Rose, A., Spiegel, M., 2004. A gravity model of sovereign lending: trade, default, and credit. IMF Staff Papers 51(1), 50-63.

[52] Shleifer, A., Wolfenzon, D., 2003. Investor protection and equity markets. Journal of Financial Economics 66(1), 3-27. 
[53] Shleifer, A., Vishny, R., 1997. A survey of corporate governance. Journal of Finance 52(2), 737-783.

[54] Spiegel, M., 2009a. Monetary and financial integration: evidence from the EMU. Journal of the Japanese and International Economies 23(2), 114-130.

[55] Spiegel, M., 2009b. Monetary and financial integration in the EMU: push or pull? Review of International Economics 17(4), 751-776.

[56] Wei, S.-J., 2000. How taxing is corruption on international investors? Review of Economics and Statistics, February 82(1), 1-11.

[57] Wooldridge, P. D., 2002. Uses of the BIS statistics: an introduction. BIS (Basle, Switzerland) Quarterly Review, March. 
Table 1: Legislative Measures (Directives) of the Financial Services Action Plan (FSAP)

Directive No. Directive Title

Deadline

1998/26/EC Implementation of the Settlement Finality Directive

2000/46/EC Directive on the taking up, pursuit and prudential supervision of the businesses of electronic money institutions

$27 / 04 / 2002$

2000/64/EC Directive amending the insurance directives and the ISD to permit Information exchange with third countries

$17 / 11 / 2002$

2001/17/EC Directive on the reorganisation and winding-up of Insurance undertakings

$20 / 04 / 2003$

2001/24/EC Directive on the reorganisation and winding-up of banks

$5 / 5 / 2004$

2001/65/EC Directive amending the 4th and 7th Company Law Directives to allow fair value accounting

$9 / 10 / 2004$

2001/86/EC Directive supplementing the Statute for a European Company with regard to the envolvement of employees

$10 / 10 / 2004$

2001/97/EC Directive amending the money laundering directive

9 2001/107/EC 1st Directive on UCITS (Undertakings for Collective Investments in Transferable Securities)

$15 / 06 / 2003$

$13 / 08 / 2003$

1 2001/108/EC 2nd Directive on UCITS (Undertakings for Collective Investments in Transferable Securities)

$13 / 08 / 2003$

2002/13/EC Directive amending the solvency margin requirements in the insurance directives

$20 / 09 / 2003$

2002/47/EC Directive on financial collateral arrangements

$17 / 12 / 2003$

2002/65/EC Directive on the Distance marketing of Financial Services

$1 / 01 / 2004$

14 2002/87/EC Directive on the supervision of credit institutions, insurance undertakings and investment firms in a financial conglomerate

15 2002/83/EC Solvency 1 Directive for life insurance

16 2002/92/EC Directive on insurance mediation

$11 / 8 / 2004$

$2003 / 4$

2003/6/EC Directive on insider dealing and market manipulation

$20 / 09 / 2003$

$15 / 01 / 2005$

$12 / 10 / 2004$

18 2003/41/EC Directive on the prudential supervision of pension funds

$23 / 09 / 2005$

19 2003/48/EC Directive on the taxation of savings income in the form of interest payments

$1 / 1 / 2004$

2003/51/EC Directive modernising the accounting provisions of the 4th and 7th Company Law Directives

$1 / 01 / 2005$

21 2003/71/EC Directive on prospectuses

$1 / 07 / 2005$

22 2004/25/EC Directive on Take Over Bids

$5 / 20 / 2006$

23 2004/109/EC Transparency Directive

$1 / 20 / 2007$

2004/39/EC Directive on Markets in Financial Instruments (update of ISD) - MiFID

$1 / 20 / 2007$

2005/56/EC 10th Company law Directive on cross-border mergers

$12 / 15 / 2007$

2006/48/EC Directive on the relating to the taking up and pursuit of the business of credit institutions

$12 / 31 / 2006$

27 2006/49/EC Directive on the capital adequacy of investment firms and credit institutions

$12 / 31 / 2006$

The Table reports the timing of circulation by the EU Commission of the 27 Dircetives of legislative-regulatory harmonization in banking, insurance, and capital markets included in the Financial Services Action Plan (FSAP). Section 2.2 and the Supplementary Appendix give details for each of the FSAP Directives. 
Table 2: Transposition Date (Year Quarter) for the Directives of the Financial Services Action Plan (FSAP)

\begin{tabular}{|c|c|c|c|c|c|c|c|c|c|c|c|c|c|c|c|}
\hline Directive & AT & BE & DE & DK & ES & FR & FI & GR & IE & IT & $\mathbf{L U}$ & NL & PT & SE & UK \\
\hline 1998/26/EC & 1999 Q4 & 1999 Q2 & 1999 Q4 & 2000 Q2 & 1999 Q4 & 2001 Q2 & 1999 Q4 & 2000 Q1 & 1999 Q1 & $2001 \mathrm{Q} 2$ & 2001 Q1 & 1999 Q1 & 2000 Q1 & 2000 Q1 & 1999 Q4 \\
\hline 2000/46/EC & 2002 Q2 & 2003 Q2 & 2002 Q3 & 2005 Q1 & 2002 Q4 & 2003 Q1 & 2003 Q1 & 2003 Q2 & 2002 Q2 & 2002 Q2 & 2002 Q2 & 2002 Q3 & 2002 Q1 & 2002 Q2 & 2002 Q2 \\
\hline 2000/64/EC & 2003 Q3 & 2004 Q1 & 2002 Q1 & 2004 Q1 & 2002 Q4 & 2006 Q1 & 2004 Q2 & 2004 Q4 & Not Yet & Not Yet & 2001 Q3 & 2003 Q1 & 2000 Q4 & 2000 Q3 & 2003 Q2 \\
\hline 2001/17/EC & 2003 Q3 & 2004 Q4 & 2003 Q4 & 2006 Q3 & 2003 Q4 & 2005 Q1 & 2004 Q2 & Not Yet & 2003 Q2 & 2003 Q2 & 2004 Q2 & 2004 Q2 & 2003 Q2 & 2006 Q2 & 2003 Q2 \\
\hline 2001/24/EC & 2003 Q3 & 2004 Q4 & 2004 Q1 & 2004 Q2 & 2005 Q2 & 2004 Q4 & 2004 Q2 & 2006 Q2 & 2004 Q2 & 2004 Q3 & 2004 Q2 & 2005 Q2 & 2006 Q4 & 2006 Q1 & 2004 Q2 \\
\hline 2001/65/EC & 2004 Q1 & 2005 Q1 & 2004 Q4 & 2002 Q1 & 2004 Q1 & 2004 Q4 & 2004 Q4 & 2006 Q2 & 2004 Q4 & 2005 Q1 & 2006 Q2 & 2005 Q3 & 2004 Q2 & 2004 Q1 & 2004 Q4 \\
\hline 2001/86/EC & 2004 Q4 & 2004 Q4 & 2004 Q4 & 2004 Q2 & 2006 Q3 & 2005 Q3 & 2004 Q4 & 2006 Q2 & 2006 Q4 & 2005 Q4 & 2006 Q3 & 2005 Q1 & 2005 Q4 & 200 & Q4 \\
\hline 2001/97/EC & 2003 Q2 & 2004 Q1 & 2002 Q3 & 2005 Q1 & 2003 Q3 & 2004 Q1 & 2003 Q2 & 2005 Q4 & 2003 Q3 & 2004 Q1 & 2004 Q4 & 2001 Q4 & 2004 Q2 & 2005 Q1 & 2004 Q2 \\
\hline 2001/107/EC & 2003 Q3 & 2004 Q2 & 2004 Q1 & 2004 Q1 & 2004 Q1 & & & & & & & & & & Q1 \\
\hline 2001/108/EC & 2003 Q3 & 2004 Q2 & 2004 Q1 & 2005 Q3 & 2004 Q1 & 2003 Q4 & 2004 Q3 & 2004 Q4 & 2003 Q4 & 2003 Q4 & 2003 Q1 & 2005 Q3 & 2004 Q1 & 2004 Q2 & 2004 Q1 \\
\hline 2002/13/EC & 2003 Q3 & 2004 Q1 & 2004 Q1 & 2004 Q1 & & & & & & & & & & & 4 Q1 \\
\hline 2002/47/EC & 2003 Q4 & 2005 Q1 & 2004 Q2 & 2004 Q4 & 2002 Q4 & 2005 Q1 & 2004 Q1 & 2004 Q4 & 2004 Q1 & 2004 Q3 & 2005 Q3 & 2004 Q2 & 2004 Q2 & 2005 Q2 & 2005Q4 \\
\hline 2002/65/EC & 2004 Q4 & 2006 Q1 & 2004 Q4 & 2005Q3 & Not Yet & 2005 Q2 & 2005 Q2 & 2005 Q2 & 2004 Q4 & 2005 Q4 & Not Yet & 2006 Q1 & Not Yet & 2004 Q2 & 2004Q4 \\
\hline 2002/87/EC & 2005 Q1 & 2005 Q1 & 2005 Q1 & 2004 Q3 & 2005 Q2 & 2004 Q4 & 2004 Q3 & 2006 Q2 & 2005 Q1 & 2005 Q3 & 2006 Q4 & 2007 Q1 & Not Yet & 2006 Q3 & 4 Q3 \\
\hline 2002/83/EC & 2003 Q3 & 2004 Q2 & 2004 Q1 & 2004 Q1 & 2004 Q1 & 2004 Q2 & 2004 Q2 & 2005 Q1 & 2005 Q1 & 2004 Q1 & 2004 Q2 & 2003 Q4 & 2003 Q4 & 2004 Q2 & 5 Q1 \\
\hline 2002/92/EC & 2004 Q4 & 2005 Q1 & Not Yet & 2005 Q3 & 2006 Q3 & 2005 Q4 & 2005 Q3 & 2005 Q1 & 2005 Q1 & 2006 Q2 & 2005 Q4 & 2005 Q3 & 2006 Q4 & 2005 Q3 & 2005 Q1 \\
\hline 2003/6/EC & 2005 Q1 & 2005 Q3 & 2004 Q4 & 2005 Q2 & 2005 Q4 & 2005 Q3 & 2005 Q3 & 2005 Q3 & 2005 Q3 & 2005 Q2 & 2006 Q2 & 2005 Q4 & 2006 Q2 & 2005 Q3 & 5 Q3 \\
\hline 2003/41/EC & 2005 Q3 & 2006 Q4 & 2005 Q3 & 2005 Q4 & 2005 Q1 & 2006 Q2 & 2006 Q2 & 2005 Q3 & 2005 Q3 & Not Yet & 2005 Q3 & 2006 Q1 & 2006 Q1 & 2006 Q1 & 2005 Q4 \\
\hline 2003/48/EC & 2004 Q1 & 2005 Q3 & 2005 Q1 & 2004 Q2 & 2004 Q1 & 2003 Q4 & 2004 Q1 & 2005 Q1 & 2003 Q4 & 2005 Q2 & 2005 Q2 & 2004 Q1 & 2005 Q3 & 2005 Q3 & 2005 Q1 \\
\hline 2003/51/EC & 2005 Q1 & 2006 Q1 & 2004 Q4 & 2002 Q1 & 2005 Q1 & 2004 Q4 & 2004 Q4 & 2006 Q3 & 2005 Q1 & Not Yet & 2006 Q2 & 2005 Q3 & 2005 Q1 & 2006 Q1 & 2005 Q1 \\
\hline 2003/71/EC & 2005 Q3 & 2006 Q3 & 2005 Q3 & 2005 Q2 & 2005 Q1 & 2005 Q3 & 2005 Q3 & 2005 Q4 & 2005 Q3 & Not Yet & 2005 Q3 & 2005 Q3 & 2005 Q2 & 2005 Q3 & 2005 Q3 \\
\hline 2004/25/EC & 2006 Q2 & 2007 Q3 & 2006 Q3 & 2005 Q2 & 2007 Q3 & 2006 Q2 & 2006 Q4 & 2006 Q2 & 2006 Q2 & 2007 Q4 & 2006 Q2 & 2007 Q4 & 2006 Q4 & 2006 Q3 & 2006 Q2 \\
\hline 2004/109/EC & 2007 Q4 & 2007 Q4 & 2007 Q4 & 2007 Q4 & 2007 Q4 & 2007 Q4 & 2007 Q4 & 2007 Q4 & 2007 Q4 & 2007 Q4 & 2007 Q4 & Not Yet & 2007 Q4 & 2007 Q4 & 2007 Q4 \\
\hline 2004/39/EC & 2007 Q2 & 2008 Q3 & 2007 Q1 & 2007 Q2 & 2007 Q3 & 2007 Q4 & 2007 Q1 & 2007 Q2 & 2007 Q2 & 2007 Q4 & 2008 Q3 & 2007 Q4 & 2007 Q4 & 2007 Q1 & 2007 Q1 \\
\hline 2005/56/EC & 2007 Q4 & 2008 Q3 & 2007 Q2 & 2007 Q2 & Not Yet & 2008 Q3 & 2007 Q4 & Not Yet & 2008 Q2 & 2008 Q3 & 2007 Q1 & 2008 Q3 & Not Yet & 2008 Q1 & 2007 Q4 \\
\hline 2006/48/EC & 2007 Q1 & 2007 Q4 & 2006 Q4 & 2007 Q1 & 2008 Q1 & 2007 Q2 & 2007 Q1 & 2007 Q3 & 2007 Q1 & 2007 Q1 & 2007 Q4 & 2007 Q1 & 2007 Q2 & 2007 Q1 & 2007 Q1 \\
\hline 2006/49/EC & 2007 Q4 & 2007 Q4 & 2006 Q4 & 2007 Q1 & 2008 Q1 & 2007 Q2 & 2007 Q1 & 2007 Q3 & 2007 Q1 & 2007 Q1 & 2007 Q4 & 2007 Q1 & 2007 Q2 & 2007 Q1 & 2007 Q1 \\
\hline
\end{tabular}

The Table reports the year and quarter of the transposition of each of the 27 Directives of the Financial Services Action Plan (FSAP) by EU15 countries. See Section 2.2 on details of the FSAP. Table 1 reports a brief description of each Directive. Supplementary Appendix Table A gives a brief description of each Directive. Data on the transposition of the legislativeharmonization Directives are retrived from the EU Commission and each of the EU15 countries. 
Table 3: EU membership, Euro area membership, and Banking Integration

Panel A: Panel Fixed-Effect Estimates in the Full Sample of Countries

\begin{tabular}{|c|c|c|c|c|c|c|c|c|}
\hline & \multicolumn{4}{|c|}{ Sample Period: 1978-2007 } & \multicolumn{4}{|c|}{ Sample Period: 1990-2007 } \\
\hline & $\frac{\text { BI1-Stocks }}{(1)}$ & $\frac{\text { BI2-Flows }}{(2)}$ & $\frac{\text { BI1-Stocks }}{(3)}$ & $\frac{\text { BI2-Flows }}{(4)}$ & $\frac{\text { BI1-Stocks }}{(5)}$ & $\frac{\text { BI2-Flows }}{(6)}$ & $\frac{\text { BI1-Stocks }}{(7)}$ & $\frac{\text { BI2-Flows }}{(8)}$ \\
\hline $\begin{array}{l}\text { euone (EU1) } \\
\text { t-stat }\end{array}$ & $\begin{array}{c}-0.6286 \\
(4.01)\end{array}$ & $\begin{array}{r}-0.441 \\
(3.45)\end{array}$ & $\begin{array}{r}-0.473 \\
(3.27)\end{array}$ & $\begin{array}{c}-0.3297 \\
(2.76)\end{array}$ & $\begin{array}{c}-0.4963 \\
(2.76)\end{array}$ & $\begin{array}{c}-0.5421 \\
(3.91)\end{array}$ & $\begin{array}{c}-0.4317 \\
(2.62)\end{array}$ & $\begin{array}{c}-0.4991 \\
(3.90)\end{array}$ \\
\hline $\begin{array}{l}\text { euboth (EU2) } \\
\text { t-stat }\end{array}$ & $\begin{array}{c}-0.0454 \\
(0.30)\end{array}$ & $\begin{array}{l}0.1406 \\
(1.25)\end{array}$ & $\begin{array}{c}-0.0372 \\
(0.28)\end{array}$ & $\begin{array}{l}0.1453 \\
(1.42)\end{array}$ & $\begin{array}{c}-0.0958 \\
(0.62)\end{array}$ & $\begin{array}{c}-0.0308 \\
(0.26)\end{array}$ & $\begin{array}{r}-0.136 \\
(1.05)\end{array}$ & $\begin{array}{c}-0.0575 \\
(0.57)\end{array}$ \\
\hline $\begin{array}{l}\text { euroone (EZ1) } \\
\text { t-stat }\end{array}$ & $\begin{array}{c}-0.0082 \\
(0.05)\end{array}$ & $\begin{array}{l}0.0357 \\
(0.24)\end{array}$ & $\begin{array}{r}-0.308 \\
(2.00)\end{array}$ & $\begin{array}{c}-0.1719 \\
(1.20)\end{array}$ & $\begin{array}{c}-0.0655 \\
(0.47)\end{array}$ & $\begin{array}{c}-0.0138 \\
(0.11)\end{array}$ & $\begin{array}{c}-0.2365 \\
(1.88)\end{array}$ & $\begin{array}{l}-0.128 \\
(1.04)\end{array}$ \\
\hline $\begin{array}{l}\text { euroboth }(E Z 2) \\
\text { t-stat }\end{array}$ & $\begin{array}{l}0.6241 \\
(3.53)\end{array}$ & $\begin{array}{l}0.535 \\
(4.13)\end{array}$ & $\begin{array}{l}0.3474 \\
(2.56)\end{array}$ & $\begin{array}{l}0.3431 \\
(3.24)\end{array}$ & $\begin{array}{l}0.5417 \\
(4.41)\end{array}$ & $\begin{array}{l}0.4692 \\
(5.16)\end{array}$ & $\begin{array}{l}0.368 \\
(3.68)\end{array}$ & $\begin{array}{l}0.3539 \\
(4.48)\end{array}$ \\
\hline $\begin{array}{l}\text { Real p.c. GDP (GDP) } \\
\text { t-stat }\end{array}$ & & & $\begin{array}{l}3.0715 \\
(8.08)\end{array}$ & $\begin{array}{l}2.1272 \\
(7.69)\end{array}$ & & & $\begin{array}{l}3.1000 \\
(8.47)\end{array}$ & $\begin{array}{l}2.0623 \\
(7.58)\end{array}$ \\
\hline $\begin{array}{l}\text { Year FE } \\
\text { Country-Pair FE }\end{array}$ & $\begin{array}{l}\text { Yes } \\
\text { Yes }\end{array}$ & $\begin{array}{l}\text { Yes } \\
\text { Yes }\end{array}$ & $\begin{array}{l}\text { Yes } \\
\text { Yes }\end{array}$ & $\begin{array}{l}\text { Yes } \\
\text { Yes }\end{array}$ & $\begin{array}{l}\text { Yes } \\
\text { Yes }\end{array}$ & $\begin{array}{l}\text { Yes } \\
\text { Yes }\end{array}$ & $\begin{array}{l}\text { Yes } \\
\text { Yes }\end{array}$ & $\begin{array}{l}\text { Yes } \\
\text { Yes }\end{array}$ \\
\hline $\begin{array}{l}\text { Observations } \\
\text { Within R-squared } \\
\text { Country-pairs }\end{array}$ & $\begin{array}{c}5566 \\
0.500 \\
190\end{array}$ & $\begin{array}{c}5566 \\
0.566 \\
190\end{array}$ & $\begin{array}{c}5566 \\
0.596 \\
190\end{array}$ & $\begin{array}{c}5566 \\
0.613 \\
190\end{array}$ & $\begin{array}{c}3385 \\
0.321 \\
190\end{array}$ & $\begin{array}{c}3386 \\
0.378 \\
190\end{array}$ & $\begin{array}{c}3385 \\
0.440 \\
190\end{array}$ & $\begin{array}{c}3386 \\
0.427 \\
190\end{array}$ \\
\hline
\end{tabular}


Table 3: EU membership, Euro area membership, and Banking Integration (cont.)

Panel B: Panel Fixed-Effect Estimates in the EU15 Sample of Countries

\begin{tabular}{|c|c|c|c|c|c|c|c|c|}
\hline & \multicolumn{4}{|c|}{ Sample Period: 1978-2007 } & \multicolumn{4}{|c|}{ Sample Period: 1990-2007 } \\
\hline & $\frac{\text { BI1-Stocks }}{(1)}$ & $\frac{\text { BI2-Flows }}{(2)}$ & $\frac{\text { BI1-Stocks }}{(3)}$ & $\frac{\text { BI2-Flows }}{(4)}$ & $\frac{\text { BI1-Stocks }}{(5)}$ & $\frac{\text { BI2-Flows }}{(6)}$ & $\frac{\text { BI1-Stocks }}{(7)}$ & $\frac{\text { BI2-Flows }}{(8)}$ \\
\hline $\begin{array}{l}\text { euroone (EZ1) } \\
\text { t-stat }\end{array}$ & $\begin{array}{c}-0.1272 \\
(0.51)\end{array}$ & $\begin{array}{c}-0.0858 \\
(0.48)\end{array}$ & $\begin{array}{c}-0.2914 \\
(1.24)\end{array}$ & $\begin{array}{c}-0.1871 \\
(1.07)\end{array}$ & $\begin{array}{c}-0.1598 \\
(0.77)\end{array}$ & $\begin{array}{c}-0.0823 \\
(0.47)\end{array}$ & $\begin{array}{c}-0.2451 \\
(1.16)\end{array}$ & $\begin{array}{c}-0.1341 \\
(0.75)\end{array}$ \\
\hline $\begin{array}{l}\text { euroboth }(E Z 2) \\
\text { t-stat }\end{array}$ & $\begin{array}{l}0.4007 \\
(2.21)\end{array}$ & $\begin{array}{l}0.2593 \\
(2.01)\end{array}$ & $\begin{array}{l}0.2484 \\
(1.75)\end{array}$ & $\begin{array}{l}0.1654 \\
(1.52)\end{array}$ & $\begin{array}{l}0.2981 \\
(2.43)\end{array}$ & $\begin{array}{l}0.2527 \\
(2.79)\end{array}$ & $\begin{array}{l}0.2276 \\
(2.21)\end{array}$ & $\begin{array}{l}0.2099 \\
(2.59)\end{array}$ \\
\hline $\begin{array}{l}\text { Real p.c. GDP (GDP) } \\
\text { t-stat }\end{array}$ & & & $\begin{array}{l}2.8298 \\
(5.37)\end{array}$ & $\begin{array}{l}1.7456 \\
(4.93)\end{array}$ & & & $\begin{array}{l}2.2911 \\
(4.19)\end{array}$ & $\begin{array}{l}1.3923 \\
(4.05)\end{array}$ \\
\hline $\begin{array}{l}\text { Year FE } \\
\text { Country-Pair FE }\end{array}$ & $\begin{array}{l}\text { Yes } \\
\text { Yes }\end{array}$ & $\begin{array}{l}\text { Yes } \\
\text { Yes }\end{array}$ & $\begin{array}{l}\text { Yes } \\
\text { Yes }\end{array}$ & $\begin{array}{l}\text { Yes } \\
\text { Yes }\end{array}$ & $\begin{array}{l}\text { Yes } \\
\text { Yes }\end{array}$ & $\begin{array}{l}\text { Yes } \\
\text { Yes }\end{array}$ & $\begin{array}{l}\text { Yes } \\
\text { Yes }\end{array}$ & $\begin{array}{l}\text { Yes } \\
\text { Yes }\end{array}$ \\
\hline $\begin{array}{l}\text { Observations } \\
\text { Within R-squared } \\
\text { Country-pairs }\end{array}$ & $\begin{array}{c}2260 \\
0.624 \\
105\end{array}$ & $\begin{array}{c}2259 \\
0.687 \\
105\end{array}$ & $\begin{array}{c}2260 \\
0.704 \\
105\end{array}$ & $\begin{array}{c}2259 \\
0.720 \\
105\end{array}$ & $\begin{array}{c}1679 \\
0.525 \\
105\end{array}$ & $\begin{array}{c}1678 \\
0.580 \\
105\end{array}$ & $\begin{array}{c}1679 \\
0.585 \\
105\end{array}$ & $\begin{array}{c}1678 \\
0.602 \\
105\end{array}$ \\
\hline
\end{tabular}

The Table reports panel fixed-effect estimates. All specifications include year fixed-effects and country-pair fixed-effects. Panel A reports coefficients estimated in the full sample of countries, while Panel B reports coefficients of otherwise identical specifications estimated only in countries that are EU members. In both Panels, columns (1)-(4) give coefficients of specifications estimated in the period 1978-2007, while columns (5)-(8) report coefficients of specifications estimated in the period 1990-2007.

In odd-numbered columns, the dependent variable (banking integration) is the average of the log of real bilateral assets and liabilities holdings of banks in countries $i$ and $j$ in year $t$, standardized by the sum of the two countries' population in each year (BI1). In even-numbered columns, the dependent variable (banking integration) is the average of the $\log$ of real bilateral gross flows in assets and liabilities of banks in countries $i$ and $j$ in year $t$, standardized by the sum of the two countries' population in each year (BI2). EU1 is an indicator (dummy) variable that takes on the value of one if only one counterpart in each pair of countries is member of the EU in year $t$ and zero otherwise. EU2 is an indicator (dummy) variable that takes on the value one if both countries are members of the EU in year $t$ and zero otherwise. EZ1 is an indicator (dummy) variable that takes on the value of one if only one counterpart in each pair of countries is member of the euro area in year $t$ and zero otherwise. EZ2 is an indicator (dummy) variable that takes on the value one if both countries are members of the euro area in year $t$ and zero otherwise. Real p.c. GDP is the log of the product of real per capita GDP of the two countries in year The Data Appendix gives detailed variable definitions and data sources. $t$-statistics based on country-pair specific (clustered) heteroskedasticity and autocorrelation are reported in parenthesis below the coefficient estimates. The Table also reports the number of country-pairs, the number of observations, and the within R-squared. 


\section{Table 4: Euro Membership, Exchange Rate Regime, and Banking Integration Panel Fixed-Effects Estimates}

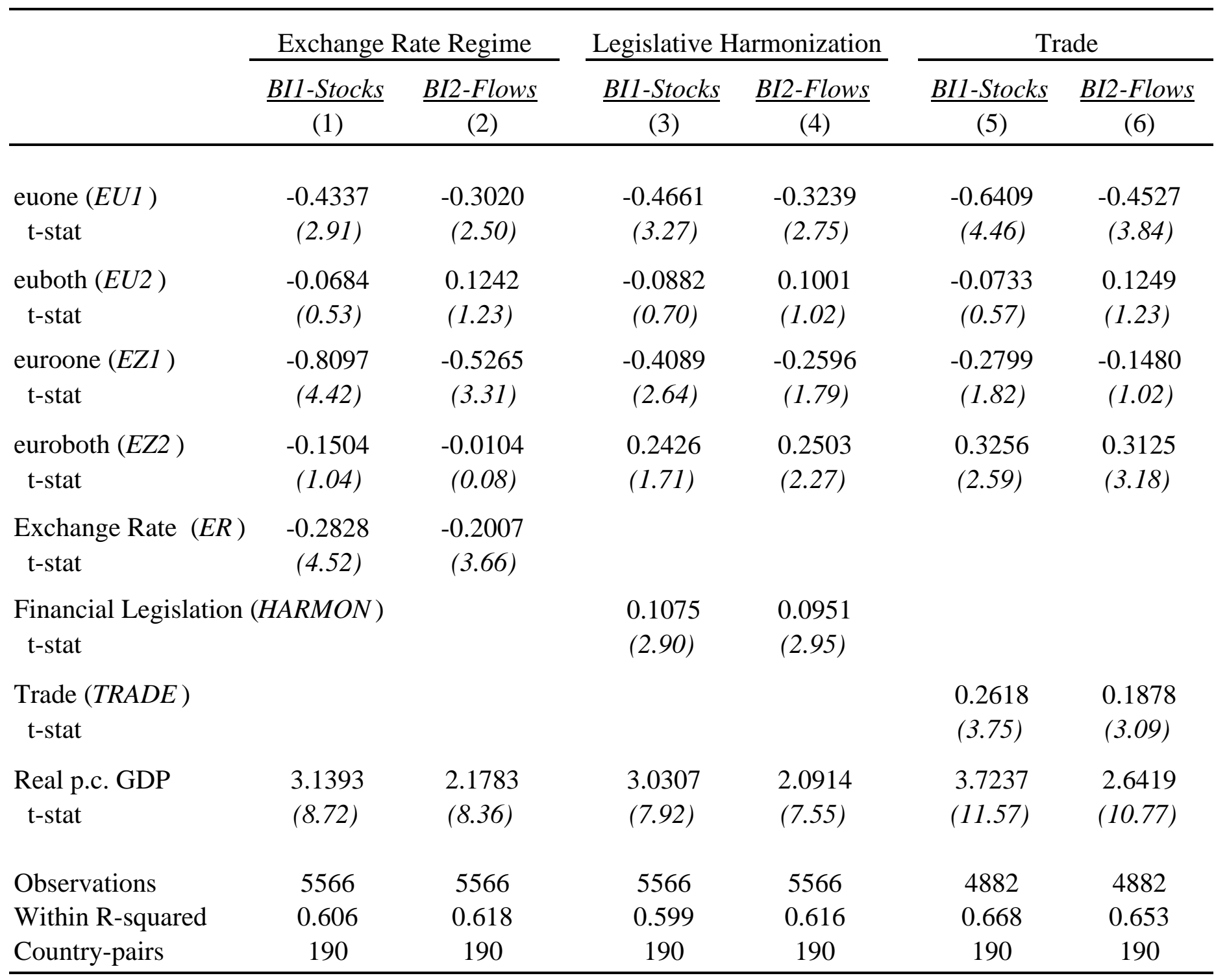

The Table reports panel fixed-effect estimates. All specifications include year fixed-effects and country-pair fixed-effects. In oddnumbered columns, the dependent variable (banking integration) is the average of the log of real bilateral assets and liabilities holdings of banks in countries $i$ and $j$ in year $t$, standardized by the sum of the two countries' population in each year (BI1). In evennumbered columns, the dependent variable (banking integration) is the average of the log of real bilateral gross flows in assets and liabilities of banks in countries $i$ and $j$ in year $t$, standardized by the sum of the two countries' population in each year (BI2). EU1 is an indicator variable that takes on the value of one if only one counterpart in each pair of countries is member of the EU in year $t$ and zero otherwise. EU2 is an indicator variable that takes on the value one if both countries are members of the EU in year $t$ and zero otherwise. EZ1 is an indicator variable that takes on the value of one if only one counterpart in each pair of countries is member of the euro area in year $t$ and zero otherwise. EZ2 is an indicator variable that takes on the value one if both countries are members of the euro area in year $t$ and zero otherwise. Real p.c. GDP is the log of the product of real per capita GDP of the two countries in year $t$. Exchange Rate is a bilateral time-varying measure of the flexibility of the exchange rate regime (based on the “fine” classification of Reinhart and Rogoff (2004) and Ilzetzki, Reinhart and Rogoff (2008)). Financial Legislation is a bilateral time-varying measure of legislative and regulatory harmonization policies in financial services based on the transposition of the 27 Directives Financial Services Action Plan (FSAP). Trade is the log of real imports and exports as a share of the two countries' GDP. The Data Appendix gives detailed variable definitions and data sources. $t$-statistics based on country-pair specific (clustered) heteroskedasticity and autocorrelation are reported in parenthesis below the coefficient estimates. The Table also reports the number of country-pairs, the number of observations, and the within R-squared. 
Table 5: Euro Membership, Exchange Rate Regime, Financial Legislation Harmonization Policies, Trade, and Banking Integration

\begin{tabular}{|c|c|c|c|c|c|c|c|c|}
\hline & \multicolumn{2}{|c|}{$\begin{array}{c}\text { Fine Classification \& } \\
\text { FSAP } 27 \text { Directives }\end{array}$} & \multicolumn{2}{|c|}{$\begin{array}{c}\text { Fine Classification \& } \\
\text { FSAP } 21 \text { Directives }\end{array}$} & \multicolumn{2}{|c|}{$\begin{array}{c}\text { Coarse Classification \& } \\
\text { FSAP } 27 \text { Directives } \\
\end{array}$} & \multicolumn{2}{|c|}{$\begin{array}{c}\text { Coarse Classification \& } \\
\text { FSAP } 21 \text { Directives }\end{array}$} \\
\hline & $\frac{\text { BI1-Stocks }}{(1)}$ & $\frac{\text { BI2-Flows }}{(2)}$ & $\frac{\text { BI1-Stocks }}{(3)}$ & $\frac{\text { BI2-Flows }}{(4)}$ & $\frac{\text { BI1-Stocks }}{(5)}$ & $\frac{\text { BI2-Flows }}{(6)}$ & $\frac{\text { BI1-Stocks }}{(7)}$ & $\frac{\text { BI2-Flows }}{(8)}$ \\
\hline $\begin{array}{l}\text { euone }(E U 1) \\
\text { t-stat }\end{array}$ & $\begin{array}{c}-0.6098 \\
(4.24)\end{array}$ & $\begin{array}{c}-0.4329 \\
(3.69)\end{array}$ & $\begin{array}{l}-0.61 \\
(4.24)\end{array}$ & $\begin{array}{c}-0.4332 \\
(3.70)\end{array}$ & $\begin{array}{c}-0.6055 \\
(4.22)\end{array}$ & $\begin{array}{l}-0.425 \\
(3.63)\end{array}$ & $\begin{array}{c}-0.6057 \\
(4.22)\end{array}$ & $\begin{array}{c}-0.4252 \\
(3.63)\end{array}$ \\
\hline $\begin{array}{l}\text { euboth (EU2) } \\
\text { t-stat }\end{array}$ & $\begin{array}{c}-0.1279 \\
(1.05)\end{array}$ & $\begin{array}{l}0.0799 \\
(0.83)\end{array}$ & $\begin{array}{c}-0.1285 \\
(1.05)\end{array}$ & $\begin{array}{l}0.0788 \\
(0.82)\end{array}$ & $\begin{array}{r}-0.126 \\
(1.03)\end{array}$ & $\begin{array}{c}0.08 \\
(0.84)\end{array}$ & $\begin{array}{c}-0.1266 \\
(1.04)\end{array}$ & $\begin{array}{l}0.0789 \\
(0.83)\end{array}$ \\
\hline $\begin{array}{l}\text { euroone (EZ1) } \\
\text { t-stat }\end{array}$ & $\begin{array}{c}-0.5811 \\
(3.55)\end{array}$ & $\begin{array}{c}-0.3512 \\
(2.35)\end{array}$ & $\begin{array}{c}-0.5815 \\
(3.55)\end{array}$ & $\begin{array}{c}-0.3521 \\
(2.36)\end{array}$ & $\begin{array}{c}-0.4326 \\
(2.81)\end{array}$ & $\begin{array}{c}-0.2735 \\
(1.90)\end{array}$ & $\begin{array}{c}-0.4333 \\
(2.82)\end{array}$ & $\begin{array}{c}-0.2749 \\
(1.91)\end{array}$ \\
\hline $\begin{array}{l}\text { euroboth }(E Z 2) \\
\text { t-stat }\end{array}$ & $\begin{array}{l}0.0377 \\
(0.27)\end{array}$ & $\begin{array}{l}0.1153 \\
(0.97)\end{array}$ & $\begin{array}{l}0.0373 \\
(0.26)\end{array}$ & $\begin{array}{l}0.1143 \\
(0.97)\end{array}$ & $\begin{array}{l}0.1869 \\
(1.51)\end{array}$ & $\begin{array}{l}0.1964 \\
(2.06)\end{array}$ & $\begin{array}{l}0.1861 \\
(1.51)\end{array}$ & $\begin{array}{l}0.1949 \\
(2.04)\end{array}$ \\
\hline $\begin{array}{l}\text { Exchange Rate }(E R) \\
\text { t-stat }\end{array}$ & $\begin{array}{c}-0.1222 \\
(2.15)\end{array}$ & $\begin{array}{c}-0.0744 \\
(1.40)\end{array}$ & $\begin{array}{l}-0.122 \\
(2.15)\end{array}$ & $\begin{array}{r}-0.074 \\
(1.40)\end{array}$ & $\begin{array}{c}-0.1311 \\
(2.29)\end{array}$ & $\begin{array}{c}-0.1034 \\
(1.92)\end{array}$ & $\begin{array}{c}-0.1310 \\
(2.29)\end{array}$ & $\begin{array}{c}-0.1031 \\
(1.92)\end{array}$ \\
\hline $\begin{array}{l}\text { Financial Legislation (HARMON) } \\
\text { t-stat }\end{array}$ & $\begin{array}{l}0.0829 \\
(2.44)\end{array}$ & $\begin{array}{l}0.0743 \\
(2.47)\end{array}$ & $\begin{array}{l}0.0852 \\
(2.44)\end{array}$ & $\begin{array}{l}0.0775 \\
(2.50)\end{array}$ & $\begin{array}{l}0.0832 \\
(2.49)\end{array}$ & $\begin{array}{l}0.0728 \\
(2.45)\end{array}$ & $\begin{array}{l}0.0856 \\
(2.49)\end{array}$ & $\begin{array}{l}0.0760 \\
(2.49)\end{array}$ \\
\hline $\begin{array}{l}\text { Trade }(T R A D E) \\
\text { t-stat }\end{array}$ & $\begin{array}{l}0.2451 \\
(3.48)\end{array}$ & $\begin{array}{l}0.1736 \\
(2.84)\end{array}$ & $\begin{array}{l}0.245 \\
(3.48)\end{array}$ & $\begin{array}{l}0.1733 \\
(2.84)\end{array}$ & $\begin{array}{l}0.2441 \\
(3.48)\end{array}$ & $\begin{array}{l}0.1726 \\
(2.83)\end{array}$ & $\begin{array}{l}0.2440 \\
(3.47)\end{array}$ & $\begin{array}{l}0.1723 \\
(2.82)\end{array}$ \\
\hline $\begin{array}{l}\text { Real p.c. GDP (GDP) } \\
\text { t-stat }\end{array}$ & $\begin{array}{l}3.7212 \\
(11.67)\end{array}$ & $\begin{array}{c}2.637 \\
(10.98)\end{array}$ & $\begin{array}{l}3.7198 \\
(11.67)\end{array}$ & $\begin{array}{l}2.6354 \\
(10.98)\end{array}$ & $\begin{array}{l}3.7105 \\
(11.61)\end{array}$ & $\begin{array}{l}2.6317 \\
(10.98)\end{array}$ & $\begin{array}{l}3.7092 \\
(11.61)\end{array}$ & $\begin{array}{l}2.6303 \\
(10.98)\end{array}$ \\
\hline $\begin{array}{l}\text { Year FE } \\
\text { Country-Pair FE }\end{array}$ & $\begin{array}{l}\text { Yes } \\
\text { Yes }\end{array}$ & $\begin{array}{l}\text { Yes } \\
\text { Yes }\end{array}$ & $\begin{array}{l}\text { Yes } \\
\text { Yes }\end{array}$ & $\begin{array}{l}\text { Yes } \\
\text { Yes }\end{array}$ & $\begin{array}{l}\text { Yes } \\
\text { Yes }\end{array}$ & $\begin{array}{l}\text { Yes } \\
\text { Yes }\end{array}$ & $\begin{array}{l}\text { Yes } \\
\text { Yes }\end{array}$ & $\begin{array}{l}\text { Yes } \\
\text { Yes }\end{array}$ \\
\hline Observations & 4882 & 4882 & 4882 & 4882 & 4882 & 4882 & 4882 & 4882 \\
\hline Within R-squared & 0.672 & 0.656 & 0.672 & 0.656 & 0.672 & 0.657 & 0.672 & 0.657 \\
\hline Country-pairs & 190 & 190 & 190 & 190 & 190 & 190 & 190 & 190 \\
\hline
\end{tabular}




\section{Table 5 Notes}

The Table reports panel fixed-effect estimates. All specifications include year fixed-effects and country-pair fixed-effects. In odd-numbered columns, the dependent variable (banking integration) is the average of the log of real bilateral assets and liabilities holdings of banks in countries $i$ and $j$ in year $t$, standardized by the sum of the two countries' population in each year (BI1). In even-numbered columns, the dependent variable (banking integration) is the average of the log of real bilateral gross flows in assets and liabilities of banks in countries $i$ and $j$ in year $t$, standardized by the sum of the two countries' population in each year (BI2).

$E U 1$ is an indicator variable that takes on the value of one if only one counterpart in each pair of countries is member of the EU in year $t$ and zero otherwise. EU2 is an indicator variable that takes on the value one if both countries are members of the EU in year $t$ and zero otherwise. EZ1 is an indicator variable that takes on the value of one if only one counterpart in each pair of countries is member of the euro area in year $t$ and zero otherwise. EZ2 is an indicator variable that takes on the value one if both countries are members of the euro area in year $t$ and zero otherwise. Real p.c. GDP is the log of the product of real per capita GDP of the two countries in year $t$.

Exchange Rate is a bilateral time-varying measure of the flexibility of the exchange rate regime based on the "fine" (in columns (1)-(4)) or the coarse (in columns (5)-(8) classification of Reinhart and Rogoff (2004) and Ilzetzki, Reinhart and Rogoff (2008)). Financial Legislation is a bilateral time-varying measure of legislative and regulatory harmonization policies in financial services based on the transposition of the 27 Directives Financial Services Action Plan (in columns (1), (2), (5) and (6)) or the initial 21 Directives (in columns (3), (4), (6), and (7)). Trade denotes the log of real bilateral imports and exports as a share of the two countries' GDP. The Data Appendix gives detailed variable definitions and data sources. $t$-statistics based on country-pair specific (clustered) heteroskedasticity and autocorrelation are reported in parenthesis below the coefficient estimates. The Table also reports the number of country-pairs, the number of observations, and the within R-squared. 
Table 6: Euro Membership, Exchange Rate Regime, Financial Legislation Harmonization Policies, and Banking Integration

\begin{tabular}{|c|c|c|c|c|c|c|c|c|}
\hline & \multicolumn{2}{|c|}{$\begin{array}{c}\text { Fine Classification \& } \\
\text { FSAP } 27 \text { Directives }\end{array}$} & \multicolumn{2}{|c|}{$\begin{array}{c}\text { Fine Classification \& } \\
\text { FSAP } 21 \text { Directives }\end{array}$} & \multicolumn{2}{|c|}{$\begin{array}{c}\text { Coarse Classification \& } \\
\text { FSAP } 27 \text { Directives } \\
\end{array}$} & \multicolumn{2}{|c|}{$\begin{array}{c}\text { Coarse Classification \& } \\
\text { FSAP } 21 \text { Directives } \\
\end{array}$} \\
\hline & $\frac{\text { BI1-Stocks }}{(1)}$ & $\frac{\text { BI2-Flows }}{(2)}$ & $\frac{\text { BI1-Stocks }}{(3)}$ & $\frac{\text { BI2-Flows }}{(4)}$ & $\frac{\text { BI1-Stocks }}{(5)}$ & $\frac{\text { BI2-Flows }}{(6)}$ & $\frac{\text { BI1-Stocks }}{(7)}$ & $\frac{\text { BI2-Flows }}{(8)}$ \\
\hline $\begin{array}{l}\text { euone }(E U 1) \\
\text { t-stat }\end{array}$ & $\begin{array}{c}-0.4306 \\
(2.93)\end{array}$ & $\begin{array}{c}-0.2993 \\
(2.51)\end{array}$ & $\begin{array}{c}-0.4307 \\
(2.93)\end{array}$ & $\begin{array}{c}-0.2994 \\
(2.51)\end{array}$ & $\begin{array}{c}-0.4237 \\
(2.88)\end{array}$ & $\begin{array}{c}-0.2918 \\
(2.45)\end{array}$ & $\begin{array}{c}-0.4239 \\
(2.88)\end{array}$ & $\begin{array}{c}-0.2918 \\
(2.45)\end{array}$ \\
\hline $\begin{array}{l}\text { euboth }(E U 2) \\
\text { t-stat }\end{array}$ & $\begin{array}{l}-0.107 \\
(0.86)\end{array}$ & $\begin{array}{l}0.0882 \\
(0.91)\end{array}$ & $\begin{array}{c}-0.1073 \\
(0.87)\end{array}$ & $\begin{array}{l}0.0875 \\
(0.90)\end{array}$ & $\begin{array}{c}-0.1054 \\
(0.85)\end{array}$ & $\begin{array}{l}0.0879 \\
(0.91)\end{array}$ & $\begin{array}{c}-0.1057 \\
(0.86)\end{array}$ & $\begin{array}{l}0.0871 \\
(0.91)\end{array}$ \\
\hline $\begin{array}{l}\text { euroone (EZ1) } \\
\text { t-stat }\end{array}$ & $\begin{array}{c}-0.8603 \\
(4.71)\end{array}$ & $\begin{array}{c}-0.5716 \\
(3.57)\end{array}$ & $\begin{array}{c}-0.8606 \\
(4.71)\end{array}$ & $\begin{array}{c}-0.5725 \\
(3.58)\end{array}$ & $\begin{array}{c}-0.5384 \\
(3.36)\end{array}$ & $\begin{array}{c}-0.3579 \\
(2.43)\end{array}$ & $\begin{array}{c}-0.5388 \\
(3.36)\end{array}$ & $\begin{array}{c}-0.3592 \\
(2.44)\end{array}$ \\
\hline $\begin{array}{l}\text { euroboth (EZ2) } \\
\text { t-stat }\end{array}$ & $\begin{array}{c}-0.2043 \\
(1.40)\end{array}$ & $\begin{array}{c}-0.0599 \\
(0.47)\end{array}$ & $\begin{array}{c}-0.2046 \\
(1.40)\end{array}$ & $\begin{array}{c}-0.0609 \\
(0.48)\end{array}$ & $\begin{array}{l}0.1204 \\
(0.95)\end{array}$ & $\begin{array}{l}0.1571 \\
(1.55)\end{array}$ & $\begin{array}{l}0.1201 \\
(0.95)\end{array}$ & $\begin{array}{l}0.1558 \\
(1.54)\end{array}$ \\
\hline $\begin{array}{l}\text { Exchange Rate }(E R) \\
\text { t-stat }\end{array}$ & $\begin{array}{c}-0.2662 \\
(4.22)\end{array}$ & $\begin{array}{c}-0.1849 \\
(3.36)\end{array}$ & $\begin{array}{c}-0.2662 \\
(4.22)\end{array}$ & $\begin{array}{c}-0.1847 \\
(3.36)\end{array}$ & $\begin{array}{c}-0.2964 \\
(4.60)\end{array}$ & $\begin{array}{c}-0.2265 \\
(4.01)\end{array}$ & $\begin{array}{c}-0.2966 \\
(4.60)\end{array}$ & $\begin{array}{c}-0.2264 \\
(4.01)\end{array}$ \\
\hline $\begin{array}{l}\text { Financial Legislation (HARMON) } \\
\text { t-stat }\end{array}$ & $\begin{array}{l}0.0854 \\
(2.36)\end{array}$ & $\begin{array}{l}0.0792 \\
(2.51)\end{array}$ & $\begin{array}{l}0.087 \\
(2.34)\end{array}$ & $\begin{array}{l}0.0819 \\
(2.52)\end{array}$ & $\begin{array}{l}0.0847 \\
(2.39)\end{array}$ & $\begin{array}{l}0.0774 \\
(2.49)\end{array}$ & $\begin{array}{l}0.0865 \\
(2.38)\end{array}$ & $\begin{array}{l}0.0802 \\
(2.51)\end{array}$ \\
\hline $\begin{array}{l}\text { Real p.c. GDP (GDP) } \\
\text { t-stat }\end{array}$ & $\begin{array}{l}3.1029 \\
(8.55)\end{array}$ & $\begin{array}{l}2.1445 \\
(8.20)\end{array}$ & $\begin{array}{l}3.1016 \\
(8.54)\end{array}$ & $\begin{array}{l}2.1428 \\
(8.20)\end{array}$ & $\begin{array}{l}3.0896 \\
(8.56)\end{array}$ & $\begin{array}{l}2.1380 \\
(8.25)\end{array}$ & $\begin{array}{l}3.0883 \\
(8.55)\end{array}$ & $\begin{array}{l}2.1364 \\
(8.24)\end{array}$ \\
\hline $\begin{array}{l}\text { Year FE } \\
\text { Country-Pair FE }\end{array}$ & $\begin{array}{l}\text { Yes } \\
\text { Yes }\end{array}$ & $\begin{array}{l}\text { Yes } \\
\text { Yes }\end{array}$ & $\begin{array}{l}\text { Yes } \\
\text { Yes }\end{array}$ & $\begin{array}{l}\text { Yes } \\
\text { Yes }\end{array}$ & $\begin{array}{l}\text { Yes } \\
\text { Yes }\end{array}$ & $\begin{array}{l}\text { Yes } \\
\text { Yes }\end{array}$ & $\begin{array}{l}\text { Yes } \\
\text { Yes }\end{array}$ & $\begin{array}{l}\text { Yes } \\
\text { Yes }\end{array}$ \\
\hline Observations & 5566 & 5566 & 5566 & 5566 & 5566 & 5566 & 5566 & 5566 \\
\hline Within R-squared & 0.608 & 0.620 & 0.608 & 0.620 & 0.610 & 0.622 & 0.610 & 0.622 \\
\hline Country-pairs & 190 & 190 & 190 & 190 & 190 & 190 & 190 & 190 \\
\hline
\end{tabular}

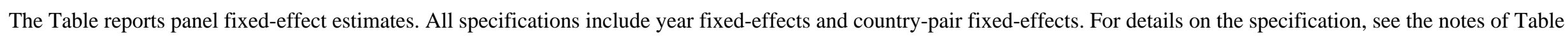

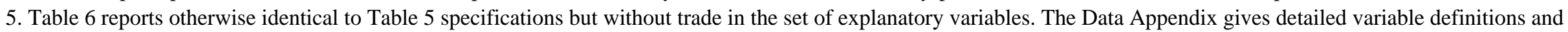
data sources. t-statistics based on country-pair specific (clustered) heteroskedasticity and autocorrelation are reported in parenthesis below the coefficient estimates. 
Table 7: Euro Membership, Exchange Rate Regime, Legislation Harmonization Policies in Financial Services, Trade, and Banking Integration. Excluding Luxemburg and Switzerland

\begin{tabular}{|c|c|c|c|c|c|c|c|c|}
\hline & $\frac{\text { BI1-Stocks }}{(1)}$ & $\frac{\text { BI2-Flows }}{(2)}$ & $\frac{\text { BI1-Stocks }}{(3)}$ & $\frac{\text { BI2-Flows }}{(4)}$ & $\frac{\text { BI1-Stocks }}{(5)}$ & $\frac{\text { BI2-Flows }}{(6)}$ & $\frac{\text { BI1-Stocks }}{(7)}$ & $\frac{\text { BI2-Flows }}{(8)}$ \\
\hline $\begin{array}{l}\text { euone (EU1) } \\
\text { t-stat }\end{array}$ & $\begin{array}{c}-0.6620 \\
(3.81)\end{array}$ & $\begin{array}{c}-0.4804 \\
(3.46)\end{array}$ & $\begin{array}{c}-0.5571 \\
(3.47)\end{array}$ & $\begin{array}{c}-0.4007 \\
(3.12)\end{array}$ & $\begin{array}{c}-0.5009 \\
(3.12)\end{array}$ & $\begin{array}{c}-0.3592 \\
(2.83)\end{array}$ & $\begin{array}{c}-0.5725 \\
(3.60)\end{array}$ & $\begin{array}{l}-0.403 \\
(3.17)\end{array}$ \\
\hline $\begin{array}{l}\text { euboth (EU2) } \\
\text { t-stat }\end{array}$ & $\begin{array}{c}-0.0122 \\
(0.08)\end{array}$ & $\begin{array}{l}0.1535 \\
(1.32)\end{array}$ & $\begin{array}{l}0.0335 \\
(0.28)\end{array}$ & $\begin{array}{l}0.1841 \\
(1.95)\end{array}$ & $\begin{array}{c}-0.0542 \\
(0.49)\end{array}$ & $\begin{array}{l}0.1117 \\
(1.29)\end{array}$ & $\begin{array}{c}-0.1177 \\
(0.96)\end{array}$ & $\begin{array}{l}0.0704 \\
(0.72)\end{array}$ \\
\hline $\begin{array}{l}\text { euroone (EZ1) } \\
\text { t-stat }\end{array}$ & $\begin{array}{l}0.0458 \\
(0.24)\end{array}$ & $\begin{array}{l}0.1580 \\
(1.02)\end{array}$ & $\begin{array}{c}-0.2300 \\
(1.43)\end{array}$ & $\begin{array}{c}-0.0379 \\
(0.27)\end{array}$ & $\begin{array}{c}-0.7252 \\
(4.02)\end{array}$ & $\begin{array}{c}-0.3977 \\
(2.52)\end{array}$ & $\begin{array}{c}-0.5873 \\
(3.40)\end{array}$ & $\begin{array}{c}-0.2977 \\
(1.93)\end{array}$ \\
\hline $\begin{array}{l}\text { euroboth (EZ2) } \\
\text { t-stat }\end{array}$ & $\begin{array}{l}0.6737 \\
(3.41)\end{array}$ & $\begin{array}{l}0.5881 \\
(4.19)\end{array}$ & $\begin{array}{l}0.4113 \\
(3.24)\end{array}$ & $\begin{array}{l}0.4020 \\
(4.06)\end{array}$ & $\begin{array}{c}-0.0828 \\
(0.59)\end{array}$ & $\begin{array}{c}0.0378 \\
(0.33)\end{array}$ & $\begin{array}{l}0.0021 \\
(0.01)\end{array}$ & $\begin{array}{l}0.0665 \\
(0.57)\end{array}$ \\
\hline $\begin{array}{l}\text { Exchange Rate }(E R) \\
\text { t-stat }\end{array}$ & & & & & $\begin{array}{c}-0.2114 \\
(3.52)\end{array}$ & $\begin{array}{c}-0.1455 \\
(2.70)\end{array}$ & $\begin{array}{c}-0.1511 \\
(2.59)\end{array}$ & $\begin{array}{c}-0.1043 \\
(1.94)\end{array}$ \\
\hline $\begin{array}{l}\text { Financial Legislation (HARMON) } \\
\text { t-stat }\end{array}$ & & & & & $\begin{array}{l}0.1445 \\
(3.77)\end{array}$ & $\begin{array}{l}0.1261 \\
(3.72)\end{array}$ & $\begin{array}{l}0.1314 \\
(3.46)\end{array}$ & $\begin{array}{l}0.1135 \\
(3.39)\end{array}$ \\
\hline $\begin{array}{l}\text { Trade (TRADE) } \\
\text { t-stat }\end{array}$ & & & & & & & $\begin{array}{l}0.2657 \\
(3.64)\end{array}$ & $\begin{array}{l}0.2104 \\
(3.20)\end{array}$ \\
\hline $\begin{array}{l}\text { Real p.c. GDP (GDP) } \\
\text { t-stat }\end{array}$ & & & $\begin{array}{l}4.3749 \\
(13.06)\end{array}$ & $\begin{array}{l}3.0910 \\
(12.43)\end{array}$ & $\begin{array}{l}4.3889 \\
(13.72)\end{array}$ & $\begin{array}{c}3.103 \\
(13.32)\end{array}$ & $\begin{array}{l}4.0317 \\
(12.11)\end{array}$ & $\begin{array}{l}2.8181 \\
(11.26)\end{array}$ \\
\hline $\begin{array}{l}\text { Year FE } \\
\text { Country-Pair FE }\end{array}$ & $\begin{array}{l}\text { Yes } \\
\text { Yes }\end{array}$ & $\begin{array}{l}\text { Yes } \\
\text { Yes }\end{array}$ & $\begin{array}{l}\text { Yes } \\
\text { Yes }\end{array}$ & $\begin{array}{l}\text { Yes } \\
\text { Yes }\end{array}$ & $\begin{array}{l}\text { Yes } \\
\text { Yes }\end{array}$ & $\begin{array}{l}\text { Yes } \\
\text { Yes }\end{array}$ & $\begin{array}{l}\text { Yes } \\
\text { Yes }\end{array}$ & $\begin{array}{l}\text { Yes } \\
\text { Yes }\end{array}$ \\
\hline Observations & 4482 & 4482 & 4482 & 4482 & 4482 & 4482 & 4159 & 4160 \\
\hline Within R-squared & 0.515 & 0.588 & 0.665 & 0.666 & 0.677 & 0.673 & 0.688 & 0.673 \\
\hline Country-pairs & 153 & 153 & 153 & 153 & 153 & 153 & 153 & 153 \\
\hline
\end{tabular}




\section{Table 7 Notes}

The Table reports panel fixed-effect estimates. All specifications include year fixed-effects and country-pair fixed-effects. In odd-numbered columns, the dependent variable (banking integration) is the average of the log of real bilateral assets and liabilities holdings of banks in countries $i$ and $j$ in year $t$, standardized by the sum of the two countries' population in each year (BI1). In even-numbered columns, the dependent variable (banking integration) is the average of the log of real bilateral gross flows in assets and liabilities of banks in countries $i$ and $j$ in year $t$, standardized by the sum of the two countries' population in each year (BI2).

$E U 1$ is an indicator variable that takes on the value of one if only one counterpart in each pair of countries is member of the EU in year $t$ and zero otherwise. EU2 is an indicator variable that takes on the value one if both countries are members of the EU in year $t$ and zero otherwise. EZ1 is an indicator variable that takes on the value of one if only one counterpart in each pair of countries is member of the euro area in year $t$ and zero otherwise. EZ2 is an indicator variable that takes on the value one if both countries are members of the euro area in year $t$ and zero otherwise. Real p.c. GDP is the log of the product of real per capita GDP of the two countries in year $t$.

Exchange Rate is a bilateral time-varying measure of the flexibility of the exchange rate regime based on the "fine" classification of Reinhart and Rogoff (2004) and Ilzetzki, Reinhart and Rogoff (2008)). Financial Legislation is a bilateral time-varying measure of legislative and regulatory harmonization policies in financial services based on the transposition of the 27 Directives Financial Services Action Plan. Trade denotes the log of real bilateral imports and exports as a share of the two countries' population. The Data Appendix gives detailed variable definitions and data sources. $t$-statistics based on country-pair specific (clustered) heteroskedasticity and autocorrelation are reported in parenthesis below the coefficient estimates. The Table also reports the number of country-pairs, the number of observations, and the within R-squared. 
Table 8: Euro Membership, Exchange Rate Regime, and Banking Integration Controlling for Structural Characteristics of the Banking System

\begin{tabular}{|c|c|c|c|c|c|c|}
\hline \multirow[t]{2}{*}{ Banking Characteristic } & \multicolumn{2}{|c|}{ Bank Overhead Costs } & \multicolumn{2}{|c|}{ Bank Interest Margin } & \multicolumn{2}{|c|}{ Bank Concentration } \\
\hline & $\frac{\text { BI1-Stocks }}{(1)}$ & $\frac{\text { BI2-Flows }}{(2)}$ & $\frac{\text { BI1-Stocks }}{(3)}$ & $\frac{\text { BI2-Flows }}{(4)}$ & $\frac{\text { BI1-Stocks }}{(5)}$ & $\frac{\text { BI2-Flows }}{(6)}$ \\
\hline $\begin{array}{l}\text { euone (EU1) } \\
\text { t-stat }\end{array}$ & $\begin{array}{c}-0.4600 \\
(2.74)\end{array}$ & $\begin{array}{c}-0.4937 \\
(3.29)\end{array}$ & $\begin{array}{c}-0.4471 \\
(2.71)\end{array}$ & $\begin{array}{c}-0.4775 \\
(3.19)\end{array}$ & $\begin{array}{c}-0.4558 \\
(2.77)\end{array}$ & $\begin{array}{c}-0.4878 \\
(3.30)\end{array}$ \\
\hline $\begin{array}{l}\text { euboth (EU2) } \\
\text { t-stat }\end{array}$ & $\begin{array}{c}-0.1843 \\
(1.49)\end{array}$ & $\begin{array}{c}-0.0387 \\
(0.39)\end{array}$ & $\begin{array}{c}-0.1661 \\
(1.37)\end{array}$ & $\begin{array}{c}-0.0289 \\
(0.29)\end{array}$ & $\begin{array}{c}-0.1791 \\
(1.48)\end{array}$ & $\begin{array}{c}-0.0408 \\
(0.41)\end{array}$ \\
\hline $\begin{array}{l}\text { euroone (EZ1) } \\
\text { t-stat }\end{array}$ & $\begin{array}{c}-0.7188 \\
(4.55)\end{array}$ & $\begin{array}{c}-0.4360 \\
(3.17)\end{array}$ & $\begin{array}{c}-0.6746 \\
(4.32)\end{array}$ & $\begin{array}{c}-0.4172 \\
(3.02)\end{array}$ & $\begin{array}{c}-0.6869 \\
(4.36)\end{array}$ & $\begin{array}{c}-0.4225 \\
(3.05)\end{array}$ \\
\hline $\begin{array}{l}\text { euroboth (EZ2) } \\
\text { t-stat }\end{array}$ & $\begin{array}{c}-0.1193 \\
(0.90)\end{array}$ & $\begin{array}{l}0.0519 \\
(0.49)\end{array}$ & $\begin{array}{c}-0.0883 \\
(0.66)\end{array}$ & $\begin{array}{l}0.0626 \\
(0.58)\end{array}$ & $\begin{array}{c}-0.1045 \\
(0.79)\end{array}$ & $\begin{array}{l}0.0526 \\
(0.48)\end{array}$ \\
\hline $\begin{array}{l}\text { Exchange Rate }(E R) \\
\text { t-stat }\end{array}$ & $\begin{array}{c}-0.2781 \\
(4.63)\end{array}$ & $\begin{array}{c}-0.1659 \\
(2.97)\end{array}$ & $\begin{array}{c}-0.2592 \\
(4.35)\end{array}$ & $\begin{array}{c}-0.1581 \\
(2.81)\end{array}$ & $\begin{array}{c}-0.2626 \\
(4.43)\end{array}$ & $\begin{array}{c}-0.1602 \\
(2.88)\end{array}$ \\
\hline $\begin{array}{l}\text { Financial Legislation (HARMON) } \\
\text { t-stat }\end{array}$ & $\begin{array}{l}0.0657 \\
(2.34)\end{array}$ & $\begin{array}{l}0.0477 \\
(1.81)\end{array}$ & $\begin{array}{l}0.0677 \\
(2.43)\end{array}$ & $\begin{array}{l}0.0493 \\
(1.91)\end{array}$ & $\begin{array}{l}0.0781 \\
(2.93)\end{array}$ & $\begin{array}{l}0.0575 \\
(2.32)\end{array}$ \\
\hline $\begin{array}{l}\text { Trade }(T R A D E) \\
\text { t-stat }\end{array}$ & $\begin{array}{l}0.0430 \\
(0.75)\end{array}$ & $\begin{array}{l}0.0395 \\
(0.79)\end{array}$ & $\begin{array}{l}0.0335 \\
(0.59)\end{array}$ & $\begin{array}{l}0.0340 \\
(0.68)\end{array}$ & $\begin{array}{l}0.0334 \\
(0.58)\end{array}$ & $\begin{array}{l}0.0338 \\
(0.68)\end{array}$ \\
\hline $\begin{array}{l}\text { Real p.c. GDP (GDP) } \\
\text { t-stat }\end{array}$ & $\begin{array}{l}2.6301 \\
(6.98)\end{array}$ & $\begin{array}{l}1.8637 \\
(6.11)\end{array}$ & $\begin{array}{l}2.3856 \\
(6.20)\end{array}$ & $\begin{array}{l}1.6479 \\
(5.25)\end{array}$ & $\begin{array}{l}2.3608 \\
(6.11)\end{array}$ & $\begin{array}{l}1.6352 \\
(5.27)\end{array}$ \\
\hline $\begin{array}{l}\text { Banking Characteristic Country i } \\
\text { t-stat }\end{array}$ & $\begin{array}{c}-0.0890 \\
(0.59)\end{array}$ & $\begin{array}{l}0.0778 \\
(0.51)\end{array}$ & $\begin{array}{l}0.9594 \\
(1.02)\end{array}$ & $\begin{array}{c}-0.2890 \\
(0.25)\end{array}$ & $\begin{array}{l}4.6699 \\
(1.24)\end{array}$ & $\begin{array}{l}4.4691 \\
(1.19)\end{array}$ \\
\hline $\begin{array}{l}\text { Banking Characteristic Country } j \\
\text { t-stat }\end{array}$ & $\begin{array}{l}0.0775 \\
(0.54)\end{array}$ & $\begin{array}{l}0.0866 \\
(0.68)\end{array}$ & $\begin{array}{l}1.6263 \\
(0.74)\end{array}$ & $\begin{array}{l}0.5172 \\
(0.28)\end{array}$ & $\begin{array}{c}-0.4615 \\
(0.17)\end{array}$ & $\begin{array}{c}-1.5221 \\
(0.55)\end{array}$ \\
\hline $\begin{array}{l}\text { Year FE } \\
\text { Country-Pair FE }\end{array}$ & $\begin{array}{l}\text { Yes } \\
\text { Yes }\end{array}$ & $\begin{array}{l}\text { Yes } \\
\text { Yes }\end{array}$ & $\begin{array}{l}\text { Yes } \\
\text { Yes }\end{array}$ & $\begin{array}{l}\text { Yes } \\
\text { Yes }\end{array}$ & $\begin{array}{l}\text { Yes } \\
\text { Yes }\end{array}$ & $\begin{array}{l}\text { Yes } \\
\text { Yes }\end{array}$ \\
\hline Observations & 2958 & 2959 & 2942 & 2943 & 2942 & 2943 \\
\hline Within R-squared & 0.4592 & 0.432 & 0.4359 & 0.4164 & 0.4364 & 0.4176 \\
\hline Country-pairs & 190 & 190 & 190 & 190 & 190 & 190 \\
\hline
\end{tabular}




\section{Table 8 Notes}

The Table reports panel fixed-effect estimates. All specifications include year fixed-effects and country-pair fixed-effects. In oddnumbered columns, the dependent variable (banking integration) is the average of the log of real bilateral assets and liabilities holdings of banks in countries $i$ and $j$ in year $t$, standardized by the sum of the two countries' population in each year (BI1). In evennumbered columns, the dependent variable (banking integration) is the average of the log of real bilateral gross flows in assets and liabilities of banks in countries $i$ and $j$ in year $t$, standardized by the sum of the two countries' population in each year (BI2). $E U 1$ is an indicator variable that takes on the value of one if only one counterpart in each pair of countries is member of the EU in year $t$ and zero otherwise. EU2 is an indicator variable that takes on the value one if both countries are members of the EU in year $t$ and zero otherwise. EZ1 is an indicator variable that takes on the value of one if only one counterpart in each pair of countries is member of the euro area in year $t$ and zero otherwise. EZ2 is an indicator variable that takes on the value one if both countries are members of the euro area in year $t$ and zero otherwise. GDP is the log of the product of real per capita GDP of the two countries in year $t$. Exchange Rate is a bilateral time-varying measure of the flexibility of the exchange rate regime (based on the "fine" classification of Reinhart and Rogoff (2004) and Ilzetzki, Reinhart and Rogoff (2008)). Financial Legislation is a bilateral timevarying measure of legislative and regulatory harmonization policies in financial services based on the transposition of the 27 Directives Financial Services Action Plan (FSAP). Trade is the log of real imports and exports as a share of the two countries' In all specifications we control for time-varying structural features of the banking system in country $i$ and country $j$. In columns (1)(2) we control for banks net interest margin. In columns (3)-(4) we control for banks' overhaed costs, while in columns (5)-(6) we control for a measure of banks' competition. All variables come from World Bank's Financial Structure Database (Beck, DemirgüçKunt and Levine (2000)). As these variables become available after the late 1980s, all specifications in Table 8 are estimated in the period 1990-2007.

The Data Appendix gives detailed variable definitions and data sources. $t$-statistics based on country-pair specific (clustered) heteroskedasticity and autocorrelation are reported in parenthesis below the coefficient estimates. The Table also reports the number of country-pairs, the number of observations, and the within R-squared. 